\title{
Mid-Continental Earthquakes: Spatiotemporal Occurrences, Causes, and Hazards
}

Mian Liu, Department of Geological Sciences, University of Missouri, Columbia, Missouri

Seth Stein, Department of Earth and Planetary Sciences, Northwestern University, Evanston, Illinois

\section{ABSTRACT}

Large earthquakes in North China, Australia, Northwestern Europe, Central and Eastern United States, and other mid-continents show complex spatiotemporal patterns that do not fit existing earthquake models. Individual faults or fault zones tend to fall into long term (thousands of years or longer) dormancy after a cluster of ruptures, whereas large earthquakes seem to roam between widespread faults. These behaviors are characteristic of complex dynamic systems of interacting faults. In such systems, widespread faults collectively accommodate slow tectonic loading, and a major fault rupture both transfers stress to the neighboring faults and perturbs loading conditions on distant faults. Because of the slow tectonic loading, local stress variations from fault interaction or nontectonic processes, or changes of fault strength, could trigger min-continental earthquakes. The precise spatiotemporal occurrence of large mid-continental earthquakes may be unknowable, an intrinsic limitation of complex dynamic systems, but their qualitative system behavior may be understood by a system approach. This approach would render 
some commonly used concepts, such as seismic cycles, recurrence intervals, characteristic earthquakes, and seismic gaps inadequate or irrelevant in mid-continents, and calls for rethinking of the probability estimates based on these concepts. It requires a better understanding of fault interactions on multiple spatial and temporal scales rather than focusing solely on the balance of tectonic loading and yield strength of individual faults or fault segments. It also indicates the need for paleoseismic and geodetic studies extending beyond areas where recent large earthquakes occurred, and for hazard assessments to reduce the biasing influence of the most recent large earthquakes that tend to dominate the short and incomplete earthquake records.

Key words: mid-continental earthquakes, intraplate seismicity, complex dynamic system, aftershocks, hazards.

"The potential for earthquakes along the plate boundaries has been mapped with reasonable success. Our attention should now focus on the threat posed by unanticipated quakes located in the continental interiors." (England and Jackson, 2011).

\section{INTRODUCTION}

Large earthquakes within plate interiors, although less common than earthquakes at plate boundaries, have killed more people than interplate earthquakes (Bilham, 2014). The deadliest earthquake in human history, the 1556 Huaxian earthquake (M 8.0) that killed 830,000 people (Ming et al., 1995), occurred in the middle of continental China, as 
did the 1976 Tangshan earthquake (Mw 7.8) that claimed 242,000 lives (Chen et al., 1988). Three of the largest historical earthquakes $(M \geq 7.0)$ in the continental US occurred during 1811-1812 in the New Madrid area of Missouri, in the middle of the North American continent (Hough and Page, 2011; Hough et al., 2000; Johnston and Schweig, 1996). The 2011 Virginia earthquake (M 5.8), which rattled the eastern seaboard and damaged the Washington Monument, serves as a fresh reminder of earthquake hazards in central and eastern US (Wolin et al., 2012).

"Unanticipated" is a key word differentiating interplate and intracontinental earthquakes. Most large interplate earthquakes are, or could be, anticipated, because plate tectonics predicts their general locations, and their abundance means that we often have earthquake records that seem adequate to anticipate where the next might occur. In continental interiors where faults are widespread (and often poorly mapped), which faults are active is often unclear, and earthquake records are short relative to long recurrence times, large earthquakes often come as surprises.

The complexity of mid-continental earthquakes and their challenge to current earthquake models have spurred intense interest and debates in recent years, both about their causes (e.g., Calais et al., 2016; Calais et al., 2010; Forte et al., 2007; Hough and Page, 2011; Landgraph et al., 2015; Li et al., 2005; Liu et al., 2011; Pollitz et al., 2001; Schweig and Ellis, 1994; Talwani, 2014) and the resulting hazards (Camelbeeck et al., 2007; Clark and McCue, 2003; Frankel et al., 2012; Grollimund and Zoback, 2001; Liu and Wang, 2012; Newman et al., 1999; Stein et al., 2011; Stein et al., 2012; Stein et al., 
2015b). In this review we first briefly discuss the spatiotemporal history of large earthquakes in major mid-continents, focusing on common aspects of seismicity in North China, the central and eastern US, northwestern Europe, and Australia. We then discuss current models for the causes of these earthquakes, and argue that these models are inadequate for or inapplicable to mid-continental earthquakes. We suggest a paradigm shift to treat mid-continental earthquakes as resulting from complex dynamic systems of interacting faults, and to incorporate this view in hazard assessment.

\section{ROAMING EARTHQUAKES IN MID-CONTINENTS}

Spatiotemporal patterns of seismicity form the basis for exploring their tectonic causes. The global distribution of seismicity, with earthquakes concentrating in narrow belts, played a key role in establishing plate tectonic theory (Isacks et al., 1968). Similar spatiotemporal patterns are, unfortunately, hard to identify in mid-continents from available earthquake records, which are incomplete and often too short relative to the low rates of tectonic loading. Nonetheless, a number of mid-continents, either because of exceptionally long historic records or low rates of erosion, give us some glimpse of the complex spatiotemporal behavior of mid-continental earthquakes.

\subsection{North China}

North China (or geologically the North China block), including the Ordos Plateau and the North China Plain, is part of the Achaean Sino-Korean craton within the Eurasian 
plate (Figure 1). The eastern part of the craton was rejuvenated in the Mesozoic, producing widespread volcanism and crustal extension that formed the North China Plain (Liu et al., 2004; Liu and Yang, 2005). The western part of the craton is preserved under the Ordos Plateau, which is bounded by the Weihe rift to the south and the Shanxi rift to the east (Figures 1-2).

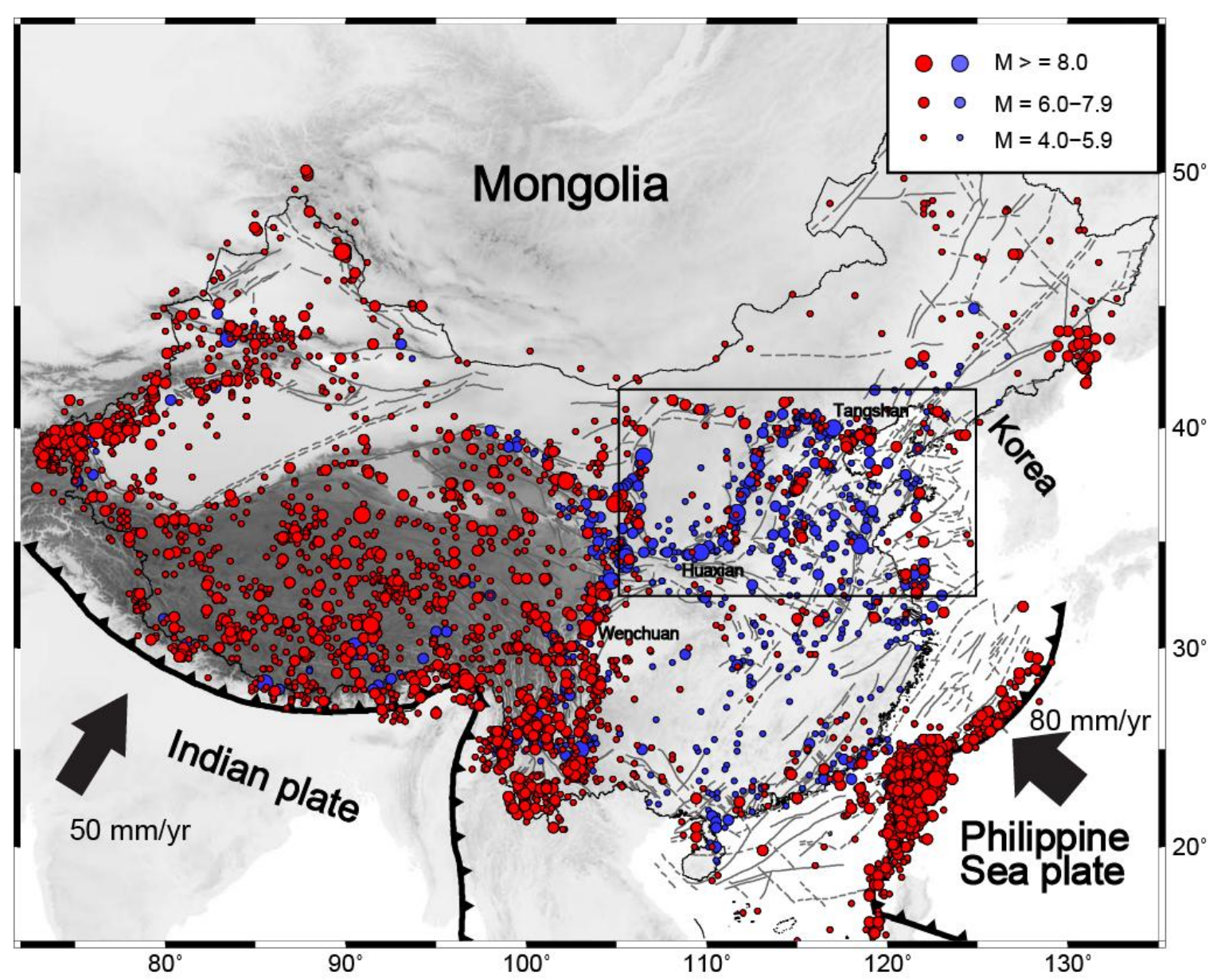

Figure 1. Topography and tectonic setting of North China (boxed) and neighboring regions. Circles are epicenters of historical (blue) and instrumentally recorded earthquakes. Thin gray lines are active faults. Arrows show plate motion relative to the stable Eurasian plate (Liu et al., 2007). 
The earthquake catalog in North China extends for nearly 3000 years (Ming et al., 1995). It is likely complete for magnitude $M \geq 6$ events since 1300 (Huang et al., 1994), a period that includes $49 \mathrm{M} \geq 6.5$ events and at least four $M \geq 8$ earthquakes. These large earthquakes appear to roam between widespread fault zones (Liu et al., 2011; Liu et al., 2014c). In 1303 the Hongdong earthquake (M 8.0) in the Shanxi rift killed more than 470,000 people. In the next 250 years, seismicity was active within the Shanxi rift (Figure 2a). In 1556, the Huaxian earthquake (M 8.3) occurred in the Weihe rift, more than $300 \mathrm{~km}$ from the epicenter of the Hongdong earthquake (Figure 2b). About 830,000 people perished, making it the deadliest earthquake in human history. The next catastrophic earthquake, the 1668 Tancheng earthquake (M 8.5), occurred more than 700 $\mathrm{km}$ east of the rift systems, in the North China Plain (Figure 2c). This earthquake ruptured the Tanlu Fault, a major Mesozoic fault that has had little Cenozoic deformation and few previous large earthquakes. GPS data show less than $1 \mathrm{~mm} / \mathrm{yr}$ slip on the Tanlu Fault today (Liu et al., 2007). A decade later, another large event, the 1679 Sanhe-Pinggu earthquake (M 8.0), occurred $\sim 40 \mathrm{~km}$ north of Beijing in a fault zone with limited previous seismicity and no clear surface exposure (Figure 2c). Then, in 1695, an $\mathrm{M} \geq 7.5$ earthquake occurred in the Shanxi rift again, near the site of the 1303 Hongdong earthquake but on a different fault (Liu et al., 2014c). 

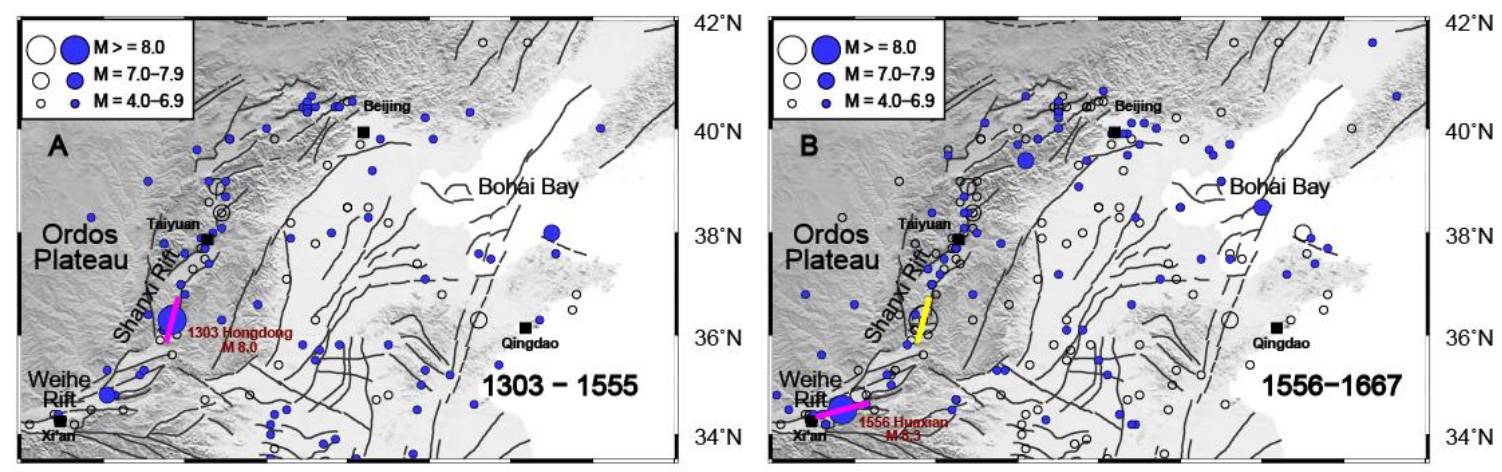

$108^{\circ} \mathrm{E} \quad 110^{\circ} \mathrm{E} \quad 112^{\circ} \mathrm{E} \quad 114^{\circ} \mathrm{E} \quad 116^{\circ} \mathrm{E} \quad 118^{\circ} \mathrm{E} \quad 120^{\circ} \mathrm{E} \quad 122^{\circ} \mathrm{E} \quad 124^{\circ} \mathrm{E} \quad 108^{\circ} \mathrm{E} \quad 110^{\circ} \mathrm{E} \quad 112^{\circ} \mathrm{E} \quad 114^{\circ} \mathrm{E} \quad 116^{\circ} \mathrm{E} \quad 118^{\circ} \mathrm{E} \quad 120^{\circ} \mathrm{E} \quad 122^{\circ} \mathrm{E} \quad 124^{\circ} \mathrm{E}$
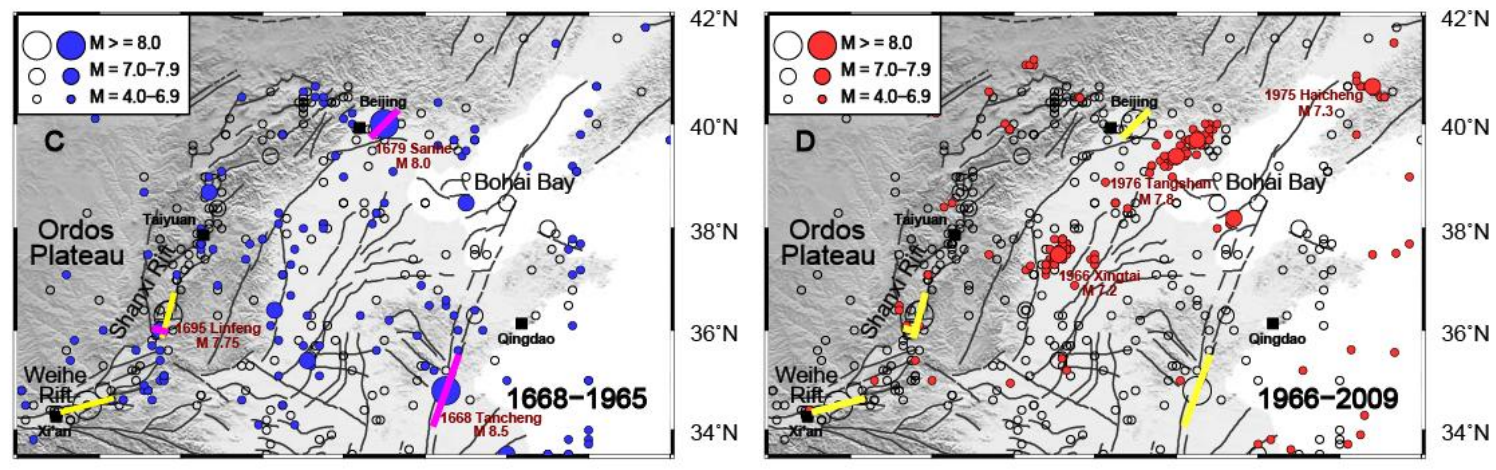

$108^{\circ} \mathrm{E} \quad 110^{\circ} \mathrm{E} \quad 112^{\circ} \mathrm{E} \quad 114^{\circ} \mathrm{E} \quad 116^{\circ} \mathrm{E} \quad 118^{\circ} \mathrm{E} \quad 120^{\circ} \mathrm{E} \quad 122^{\circ} \mathrm{E} \quad 124^{\circ} \mathrm{E} \quad 108^{\circ} \mathrm{E} \quad 110^{\circ} \mathrm{E} \quad 112^{\circ} \mathrm{E} \quad 114^{\circ} \mathrm{E} \quad 116^{\circ} \mathrm{E} \quad 118^{\circ} \mathrm{E} \quad 120^{\circ} \mathrm{E} \quad 122^{\circ} \mathrm{E} \quad 124^{\circ} \mathrm{E}$

Figure 2. Earthquake history of North China. Solid circles are the locations of events during the period indicated in each panel; open circles are the location of events from $780 \mathrm{BCE}$ to the end of the previous period (1303 CE for panel A). Red dots are epicenters of instrumentally recorded earthquakes. Bars show the rupture lengths for selected large events during (magenta) and before (yellow) the period indicated in each panel (Liu et al., 2007).

In the past 300 years the Shanxi and Weihe rifts have been largely quiescent with only a few moderate earthquakes. Meanwhile, seismicity in the North China Plain increased, including three damaging earthquakes in the past century (Figure 2d), all on previously unrecognized faults. The 1966 Xingtai earthquakes, five events with M 6.0 7.2 within 21 days, occurred in a buried rift with no surface fault traces. The 1975 Haicheng earthquake (M 7.3) occurred in a region with no major surface fault traces and little previous seismicity, and the 1976 Tangshan earthquakes (a M 7.8 event followed by 
a M 7.1 event 17 hours later) occurred on a blind fault, which had not shown even moderate seismicity in the 3000-year long Chinese catalog (Ming et al., 1995; Yin et al., 2015).

Thus large earthquakes roamed between the Shanxi and Weihe rifts, and between these rifts and the North China Plain. No large earthquakes in North China ruptured the same fault segment twice in the past 2000 years (Liu et al., 2011). Prior to that time, paleoseismic studies, while limited and with large uncertainties, indicate episodic large earthquakes separated by thousands of years of quiescence on the same fault segments (Xu and Deng, 1996b).

\subsection{NW Europe}

Although intraplate earthquakes in Northwest Europe are smaller than in North China, the patterns of seismicity in the two areas show some similarities. Much of the activity in Northwest Europe occurs in the Rhine Graben area (Figure 3). The zone is divided into the Upper Rhine Graben, extending northeastward along the topographic graben from the Basel area, and the Lower Rhine Embayment (LRE), trending northwestward toward the North Sea. The largest historical earthquake in the LRE, the 1756 Düren earthquake, had Mw 5.7, and paleoseismic investigations find evidence that large earthquakes with magnitude up to 7.0 have occurred since the late Pleistocene (Camelbeeck et al., 2014; Camelbeeck et al., 2007). The largest historical earthquake in Northwest Europe, the 1356 earthquake with estimated Mw 6.0-6.5, destroyed the city of Basel and caused 
damage in much of the Upper Rhine Graben (Meghraoui et al., 2001).

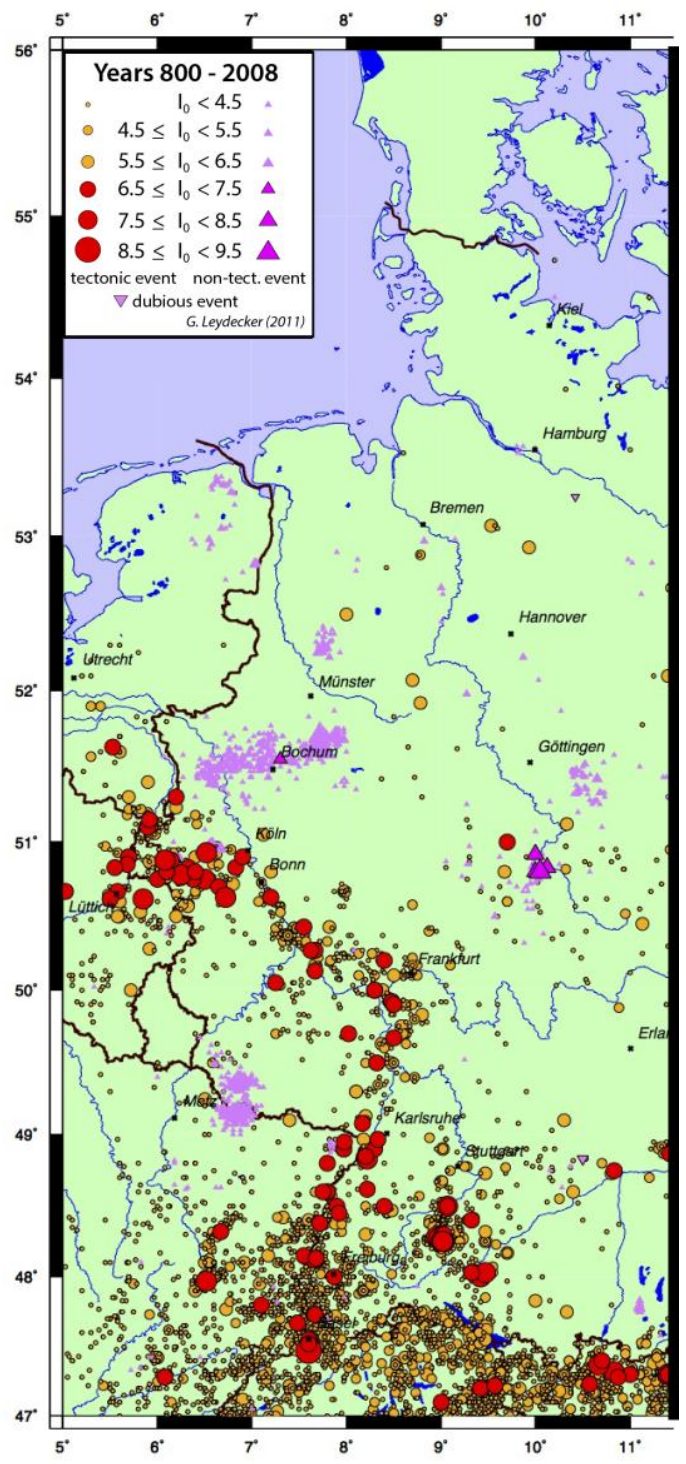

Figure 3: Historical seismicity of Northwest Europe, shown by earthquakes with different epicentral intensities, going back to $800 \mathrm{CE}$ (Leydecker, 2011).

In the past 700 years, large earthquakes moved around over the region (Figure 4), showing no particular spatial pattern (Camelbeeck et al., 2007). Hence seismicity viewed over different time intervals appears different, with different concentrations and "gaps" in different areas. 


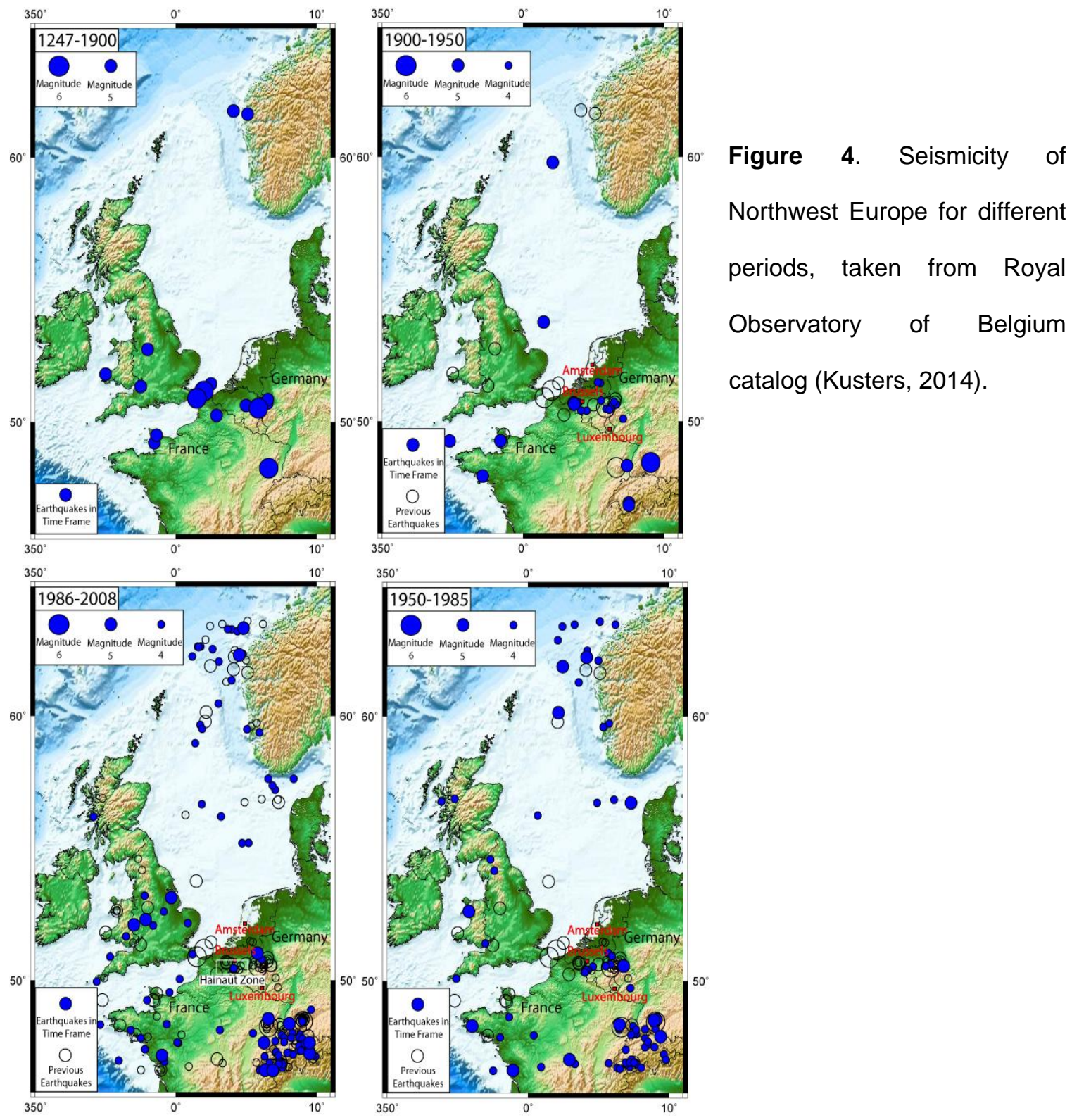

\subsection{Australia}

Australia is another stable continental region with widespread seismicity (Figure 5a)(Clark et al., 2014; Clark et al., 2012; Crone et al., 1997). Although historical records 
span only a few centuries, the very low erosion rates in much of Australia preserved rich morphogenic evidence of Neogene to Quaternary faulting (Figure 5b)(Clark et al., 2014).
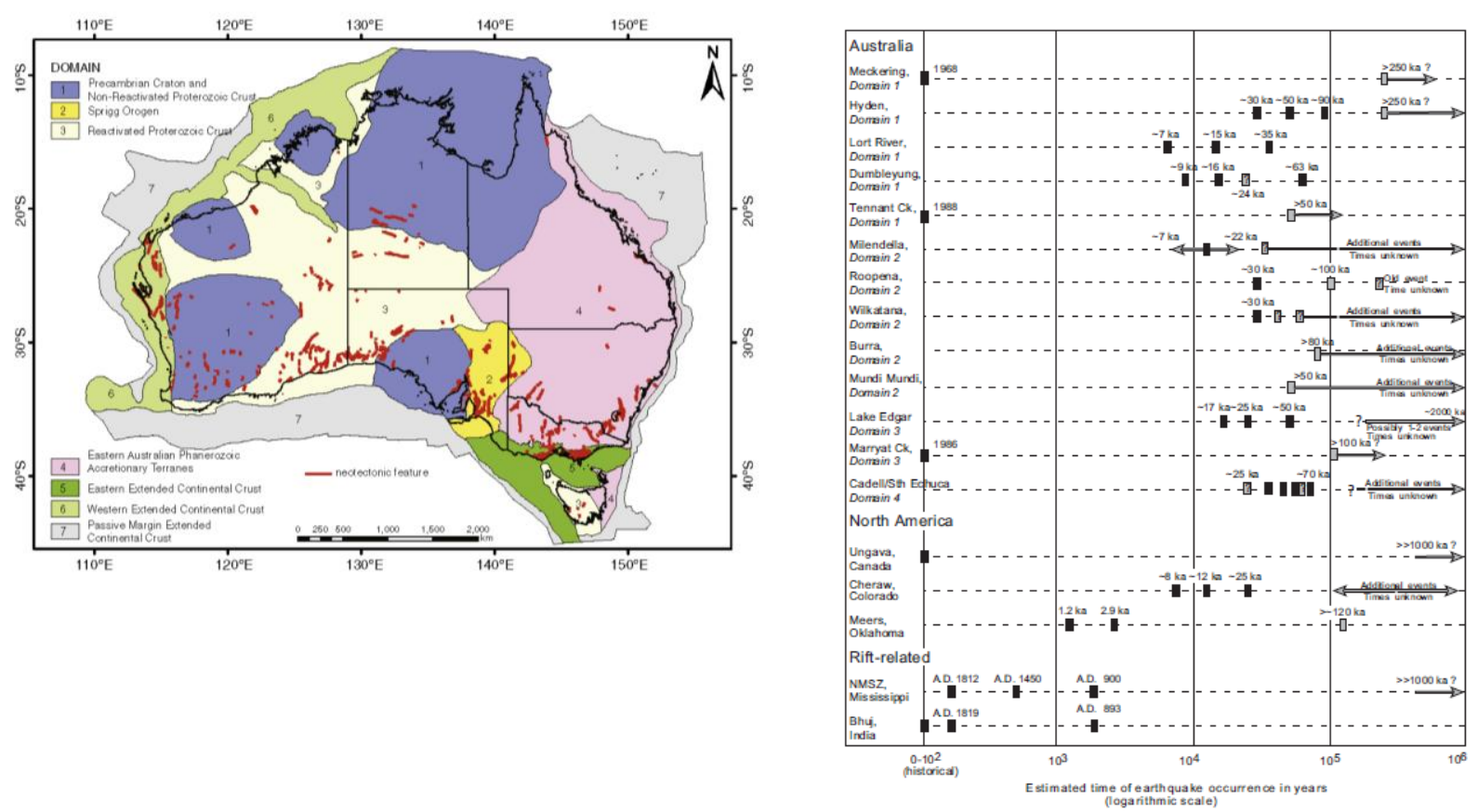

Figure 5. A. (left) Neogene to Quaternary faulting in Australia (red lines); B. (right) Their temporal clustering (Clark et al., 2012).

Although sampling bias and variable erosion rates do not permit a meaningful reconstruction of spatial occurrence of large earthquakes, Clark et al. (2012) found that "a common characteristic of morphogenic earthquake occurrence in Australia appears to be temporal clustering. Periods of earthquake activity comprising a finite number of large events are separated by much longer periods of seismic quiescence, at the scale of a single fault and of proximal faults. In several instances there is evidence for deformation at scales of several hundred kilometers switching on and off over the last several million years." The temporal pattern of these events is similar to the Devil's Staircase function 
(discussed later). As result, "assigning an 'active/inactive' label to a fault in a slowly deforming area based upon the occurrence (or non-occurrence) of an event in the last few thousands to tens of thousands of years is not a useful indicator of future seismic potential" (Clark et al., 2011) and "it is debatable whether a 'recurrence interval' on individual faults applies"(Clark, 2003).

\subsection{Central and Eastern US}

The central and eastern United States (CEUS), defined broadly as the region east of the Rocky Mountains, is in the interior of the stable North American plate. The northern part of the CEUS is within the Achaean Superior craton, which is bordered by Proterozoic and younger basement to the south and east (Van Lanen and Mooney, 2007). Failed rifting of the North American craton in the Mesoproterozoic left the Midcontinent Rift system (Stein et al., 2016 ; Van Schmus and Hinze, 1985), and disintegration of the Rodinia supercontinent in the Neoprotozoic left the Reelfoot rift and other rift systems near the eastern margin of the North American continent (Johnston and Kanter, 1990; Van Lanen and Mooney, 2007) (Figure 6). The last major tectonic event in the CEUS is the Appalachian orogeny (300-400 Ma). Cenozoic deformation within the CEUS is minimal, and GPS measurements indicate that the CEUS behaves as a rigid plate to better than $1 \mathrm{~mm} / \mathrm{yr}$ (Calais et al., 2006; Dixon et al., 1996). This stability of the CEUS lithosphere is consistent with its high-velocity seismic structure in the upper mantle, contrasting sharply with the predominantly low-velocity upper mantle structure under the western US (Burdick et al., 2012; Burdick et al., 2014; Goes and van der Lee, 2002; 
Marone et al., 2007). The lithosphere-asthenosphere boundary, inferred from tomography and other geophysical data, is $>250 \mathrm{~km}$ deep under the CEUS (e.g., Yuan and Romanowicz, 2010).

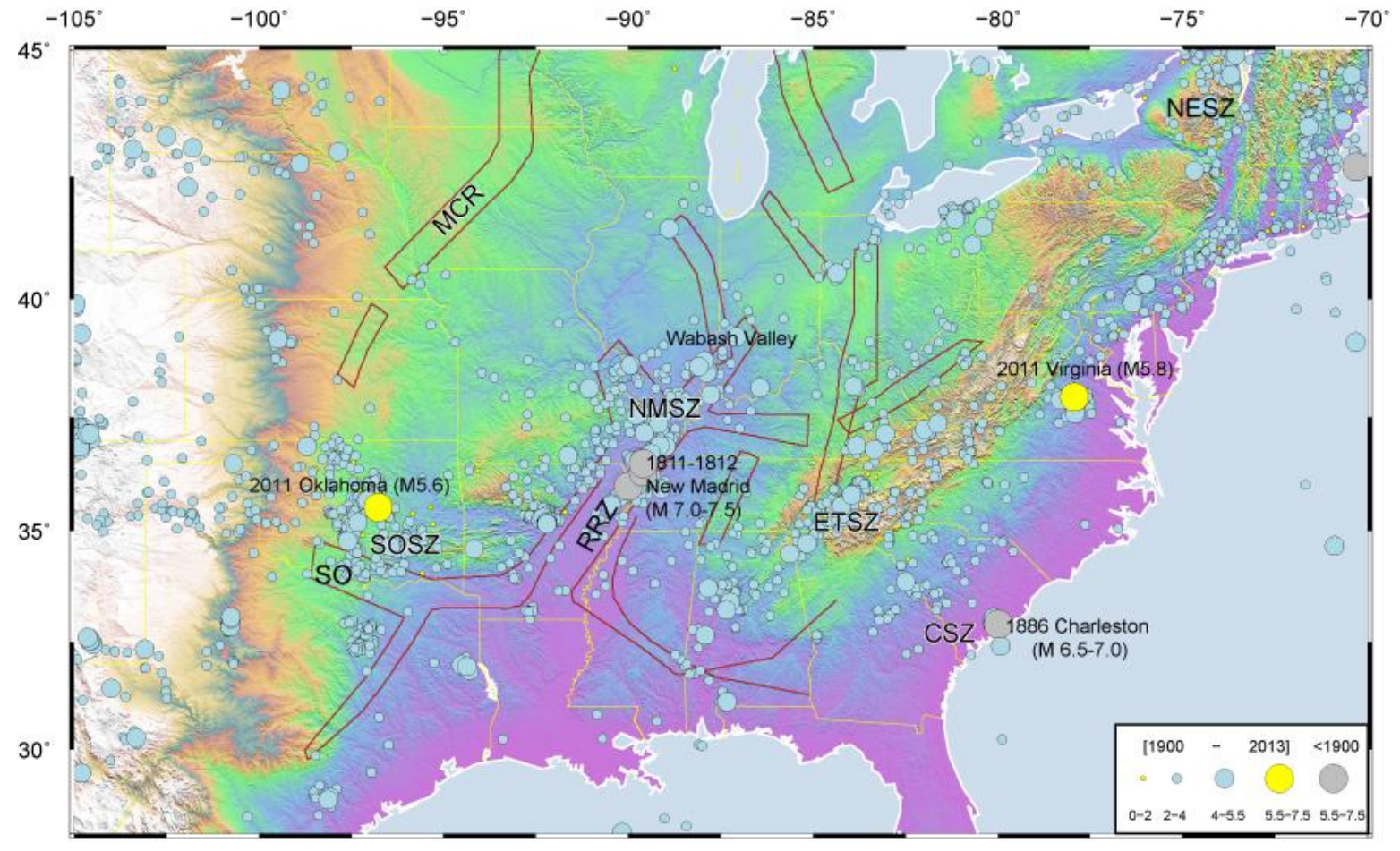

Figure 6. A topographic map of the central and eastern U.S. with earthquake epicenters. The red lines show the approximate boundaries of failed rifts. RRZ: Reelfoot Rift Zone; MCR: Midcontinent Rift; SO: Southern Oklahoma Aulacogen; NMSZ: New Madrid seismic zone; SOSZ: Southern Oklahoma seismic zone; ETSZ: Eastern Tennessee seismic zone; CSZ: Carolina seismic zone; NESZ: New England seismic zone.

Within this largely stable continent, earthquakes are widespread (Figure 6). The New Madrid seismic zone (NMSZ) is best-known for its 1811-1812 earthquakes, which include three or four large shocks ( $\mathrm{M} \geq 7.0$ ) (Hough and Page, 2011; Stein, 2010). Other 
main seismic zones include 1) The Wabash Valley seismic zone (WBSZ) in southern Illinois and Indiana, a northeastern extension of the New Madrid seismic zone, where paleoliquefaction deposits indicate the past occurrence of large earthquakes (Obermeier, 1999) that may have been comparable to those that occurred in the New Madrid zone in 1811-1812. 2) The Southern Oklahoma seismic zone (SOSZ) - Moderate seismicity has been recorded in southern Oklahoma and the Texas panhandle (Gordon, 1983), and Holocene ( 1.2 kyr ago) fault scarps on the Meers Fault indicate earthquakes of magnitude greater than 6.5 (Crone and Luza, 1990; Madole and Rubin, 1985). 3) The Eastern Tennessee seismic zone (ETSZ) includes seismicity in the Valley and Ridge province of the southern Appalachians. 4) The central Virginia seismic zone also shows clusters of seismicity, including the 2011 Mw 5.8 earthquake near Mineral. 5) The Carolina seismic zone (CSZ) is best-known for the destructive $(\mathrm{M} \sim 6.5-7.0)$ event that occurred near Charleston, South Carolina, on 31 August 1886 (Nuttli et al., 1979). Paleoseismic studies indicate at least seven prehistoric earthquakes there in the past 6000 years (Obermeier et al., 1985; Talwani and Cox, 1985). 6) The New England seismic zone (NESZ) - whose largest historic earthquakes include the Cape Ann, Massachusetts, earthquake of 1755 (M 6) (Street and Lacroix, 1979). The entire east coast, including Charleston, Virginia, and New England, can be viewed as a single seismic zone, consistent with the observation that seismicity occurs along many passive continental margins (Schulte and Mooney, 2005; Stein et al., 1989; Stein et al., 1979; Wolin et al., 2012). Further north in the St. Lawrence River valley, numerous events with magnitude 6-7 have been recorded, including the 1663 M 7.3-7.9 Charlevoix earthquake in Quebec (Ebel, 2011). 
No clear spatiotemporal patterns of seismicity can be recognized from the short catalog (a couple of centuries) in the CEUS, but seismicity is not limited to these seismic zones. Large earthquakes probably roamed across the CEUS, as they did in other stable mid-continents. The Meers Fault in Oklahoma, which produced large earthquakes about 1.2-1.3 Kyr ago (Crone and Luza, 1990), is seismically quiescent today. In the NMSZ, large earthquakes apparently repeated numerous times in the 5000 years, as indicated by paleoliquefaction data (Tuttle et al., 2002). However, increasing evidence (Figure 7) shows that large earthquakes also occurred outside the currently active New Madrid seismic zone, both within the Mississippi Embayment and beyond (e.g., Cox et al., 2007; Cox et al., 2013; Csontos et al., 2008; Guo et al., 2014; Hao et al., 2013; Holbrook et al., 2006; Tuttle et al., 2006). 


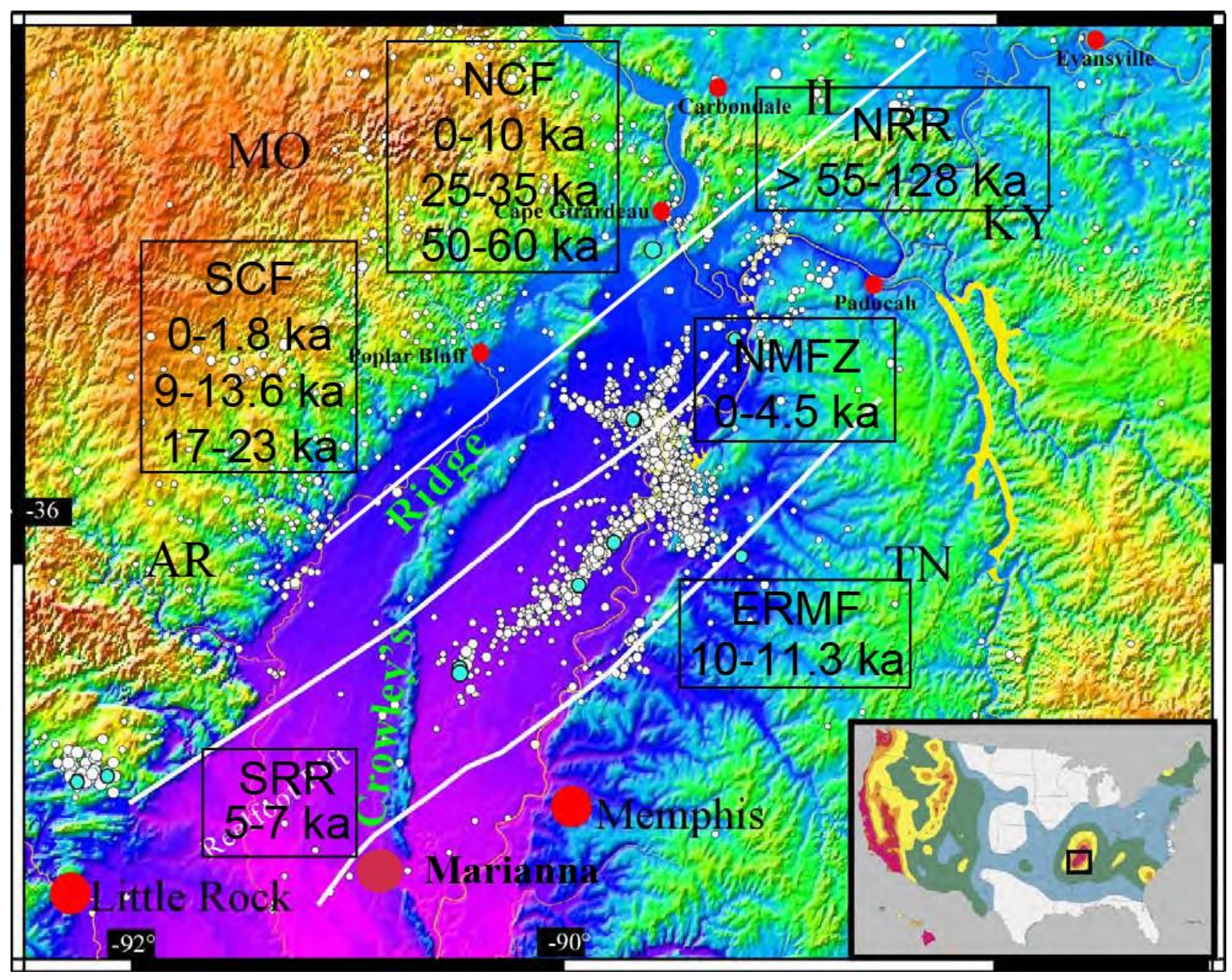

Figure 7. Locations and dates (boxes) of past earthquake activity in and near the Mississippi Embayment in the past 150,000 years, as inferred from paleoseismic data. Inset shows the location of the area in a hazard map. The current New Madrid Fault Zone (NMFZ) has been active for about 5000 years (Tuttle, 2009).

\section{MODELS OF MID-CONTINENTAL EARTHQUAKES}

The basic physics of individual interplate and intraplate earthquakes are the same: a fault ruptures when stress overcomes frictional resistance on the fault plane. Hence previous models of mid-continental earthquakes have attributed them to localized weak 
zones, loading stress, or both. However, the spatiotemporal patterns of intraplate and interplate seismicity differ.

\subsection{Structural control}

On the continental scale, lithospheric properties apppear to have a major influence on the locations of intraplate seismicity. In the CEUS, the thick and presumably strong North American craton is largely devoid of large earthquakes, which occur mainly around the edges of the craton (Van Lanen and Mooney, 2007). Similarly, although earthquakes are widespread in North China, the Ordos block, a relic of the thermally rejuvenated North China craton with a thick lithosphere (Bao et al., 2011), is largely aseismic (Figures 1 and 2). Concentration of seismicity around the margins of cratons is observed elsewhere (Craig et al., 2011; Mooney et al., 2012). One explanation is that the thick cratonic lithosphere tends to have lower deviatoric stress than the thinner lithosphere at its margins. Li et al. (2007) modeled the lateral stress variations in the CEUS caused by the variations of lithospheric thickness as inferred from seismic velocities (Burdick et al., 2014; Goes and van der Lee, 2002). Their results show concentrated deviatoric stress around the thick North American cratons and under the thinned Reelfoot rift (Figure 8). Whereas this thickness effect may explain some of the seismicity in the CEUS, Figure 8 shows that the spatial correlation between seismicity and the locations of predicted high deviatoric stress is at best partial. 

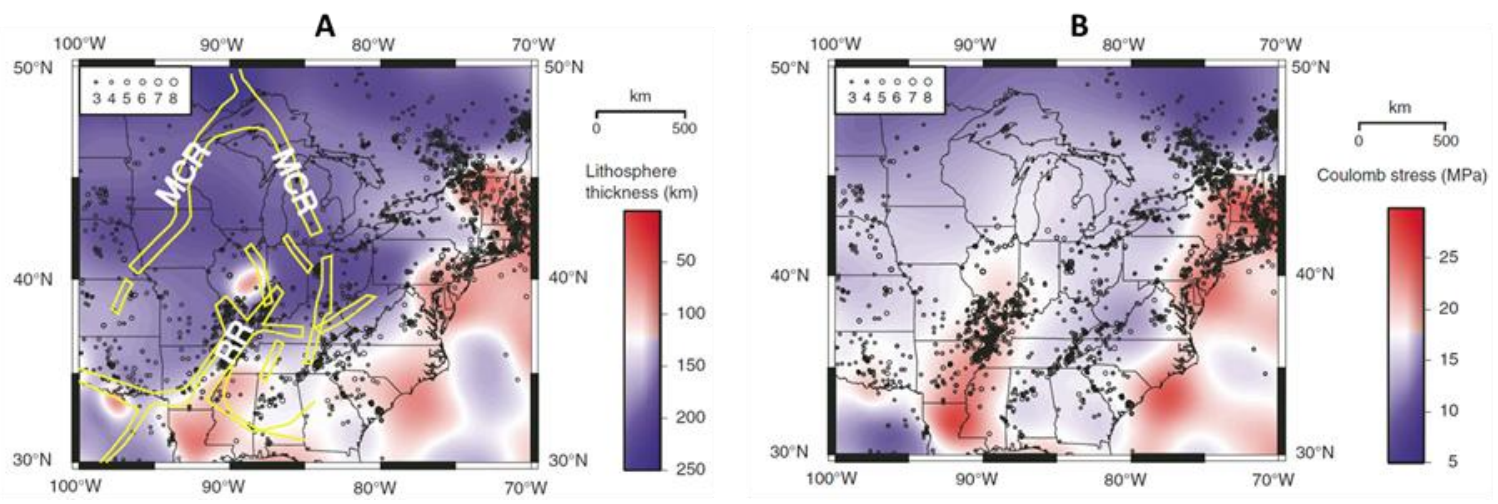

Figure 8. Variation of lithospheric thickness in the CEUS and its impact on deviatoric stresses. A. Thermal lithospheric thickness (Goes and van der Lee, 2002) and seismicity (1800-2004) in the CEUS. Yellow lines show the rift zones. MCR: Midcontinent Rift; RR: Reelfoot rift. B. Calculated optimal Coulomb stress in the crust (at $10 \mathrm{~km}$ depth). (Li et al., 2007).

Individual clusters of seismicity or seismic belts in intraplate areas are often related to rift zones (Johnston and Kanter, 1990). The NMSZ is located within the Reelfoot rift, left from the disintegration of the Rodinia supercontinent in the Neoprotozoic (Johnston and Kanter, 1990; Van Lanen and Mooney, 2007) (Figure 6). In North China, many large historic events occurred within the Shanxi-Weihe rifts (Liu et al., 2014c; Liu et al., 2007) (Figure 2). In Northwest Europe, seismicity is clustered in the Rhine graben, a Cenozoic rift system (Camelbeeck et al., 2007). In western India, earthquakes have been clustered in the Kachchh rift basins ( $\mathrm{Li}$ et al., 2002; Rastogi et al., 2014; Talwani and Gangopadhyay, 2001). However, rift zones are neither necessary nor sufficient for intraplate earthquakes. In the CEUS, not all seismic belts are related to rifts, and the Midcontinent rift, the most prominent rift in the CEUS, is essentially aseismic. In North China, the Shanxi-Weihe rift zones, which produced many large historic earthquakes, 
have been largely quiescent in the past 300 years, whereas seismicity has been active in the North China Plain (Figure 2).

Other structural features proposed as causes for intraplate seismicity include localized low-velocity structures such as those under the Reelfoot rift (Al Shukri and Mitchell, 1988; Pollitz and Mooney, 2013; Zhang et al., 2009) and the ones associated with a hotspot track (Chu et al., 2013; Cox and Van Arsdale, 1997), intersection of faults and other structures (Talwani, 1988), or faults favorably oriented to slip in response to the current stress field (Hurd and Zoback, 2012; Sbar and Sykes, 1973; Sykes, 1978). Some concentrated seismicity may result from unusual physical properties within the fault zones, such as higher than average porosity (Costain et al., 1987) or greater ductility below the seismogenic layer (Zoback, 1983).

Caution is called when seeking structural peculiarities where seismicity is clustered, because in many places the record of seismicity is too short to reflect the complete spatial pattern of seismicity ( $\mathrm{Li}$ et al., 2009). Increasing evidence shows that large earthquakes may have occurred outside presently active seismic zones (e.g., Cox et al., 2007; Cox et al., 2013; Csontos et al., 2008; Guo et al., 2014; Hao et al., 2013; Holbrook et al., 2006; Tuttle et al., 2006).

\subsection{The driving forces}

Steady tectonic loading in plate interior may derive from plate boundary forces ridge push and slab pull (Liu et al., 2007; Zoback and Zoback, 1980), basal traction - 
shear stress due to absolute plate motion and normal stress exerted by convective mantle flow (Doglioni and Panza, 2015; Forte et al., 2010; Ghosh et al., 2013; Ghosh and Holt, 2012), and gravitational body force - lateral variations of gravitational potential energy arising from internal density variations and isostatically supported topography (e.g., Artyushkov, 1973; Flesch et al., 2000; Yang and Liu, 2010).

Steady tectonic loading alone, however, cannot explain some key features of intraplate earthquakes. One is the temporal variations of seismicity with a few large earthquakes on individual faults or fault zones within thousands of years, separated by long (tens of thousands to millions of years) intervals as inferred in Australia (Clark et al., 2012) (Figure 5b). One proposed explanation is perturbations of plate boundary forces due to local changes of plate boundary geometry or properties (Clark et al., 2014; Clark et al., 2012), but such processes would usually take much longer than the typical times (thousands to tens of thousands) between clusters of intracontinental earthquakes.

The spatial clustering of seismicity within plates is often attributed to local "stress concentrators", such as intersections of faults, stepovers and bends, and other structural irregularities (Pratt, 2012; Talwani, 1988) or localized weakness in the lithosphere. Other proposed causes include local forces, such as the negative gravitational body force induced by mafic intrusions in the seismogenic rifts (Grana and Richardson, 1996; Pollitz et al., 2001), or loading from localized mantle flow (Forte et al., 2007). 
However, either plate-wide or local, steady loading has difficulty explaining the transient earthquake sequences in the NMSZ and elsewhere. Present seismicity in the NMSZ and other parts of the CEUS apparently resulted from recent fault reactivation, perhaps during the last ice age (Schweig and Ellis, 1994; Van Arsdale, 2000). Grollimund and Zoback (2001) proposed that the recent activation of the NMSZ resulted from stress changes caused by the melting of the Laurentide ice sheet. However, because flexural stresses decay rapidly away from the ice margin, this mechanism fails to explain fault activation in the NMSZ (Wu and Johnston, 2000) unless its upper mantle and lower crust are an order of magnitude weaker than the surroundings. Other proposed triggering mechanisms include sea level rise (Brothers et al., 2013), and upward flexure of the lithosphere caused by unloading from river incision (Calais et al., 2010).

\section{MID-CONTINENTAL FAULTS: A COMPLEX DYNAMIC SYSTEM}

The complex spatiotemporal variability of intraplate earthquakes is hard to assess due to the short catalogs in most regions. Catalogs are incomplete because of the low strain rates and long recurrence times, often thousands of years or longer, in mid-continents. However, limited records are not the only reason why intraplate earthquakes are more difficult to anticipate than interplate earthquakes. Although the physics of earthquakes - a fault ruptures when stress on it overcome frictional resistance - is the same for interplate and intraplate events, intraplate faults behave differently. The distribution of slow tectonic loading among a system of widespread faults makes the loading on individual intracontinental faults variable and susceptible to stress perturbations from fault 
interactions and nontectonic stress changes, resulting in a complex dynamic system that requires a different approach from interplate seismicity (Li et al., 2009; Stein et al., 2009).

\subsection{A conceptual model}

To illustrate the complex behavior of mid-continental faults, we compare it to that of an idealized plate boundary fault (Figure 9). In this simple conceptual model, interplate earthquakes are restricted to the plate boundary fault, so their general locations may be anticipated. Because the plate boundary fault is loaded by steady relative plate motion (DeMets et al., 1990), on each fault segment (assuming it is segmented, see discussion below) stress would accumulate steadily to overcome the frictional resistance on the fault plane repeatedly, yielding periodic or quasi-periodic ruptures (Figure 9a).

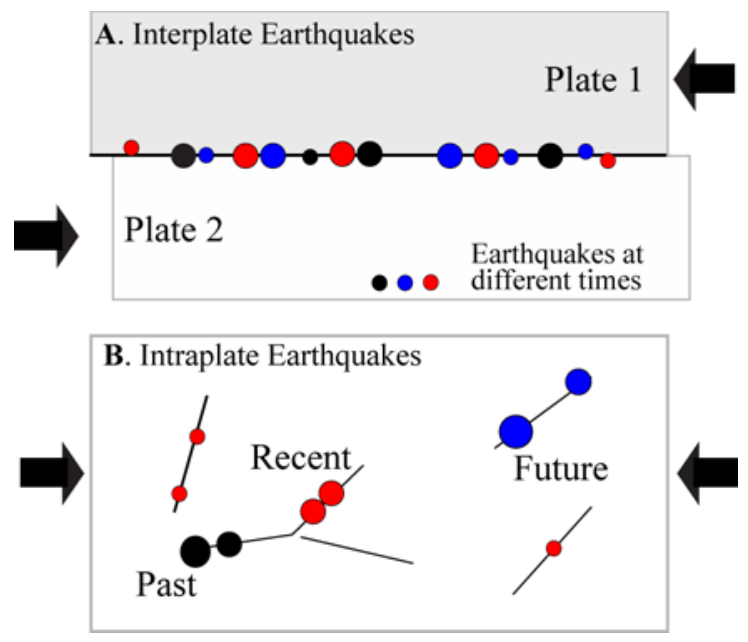

Figure 9. Conceptual models for (A) earthquakes on an idealized plate boundary fault and (B) earthquakes on a mid-continental fault system. The plate boundary fault is loaded by steady relative plate motion, yielding earthquakes concentrated along the fault. In mid-continents, slow far-field tectonic loading is shared by a complex system of interacting faults. Large earthquakes 
roam across widespread faults, as rupture of one fault zone may affect the loading on a distant fault. Modified from Liu et al. (2011).

In contrast, in mid-continents the tectonic loading is shared by a complex system of interacting faults spread over a large region (Figure 9b), such that a large rupture on one fault could affect the loading conditions on other faults ( $\mathrm{Li}$ et al., 2009). Because of the low tectonic loading rate, stress restoration on the faults that ruptured is slow, so midcontinental faults tend to fall into long dormancy after a major rupture, as has been found in Australia (Clark et al., 2012) and North China (Liu et al., 2014c). Slow tectonic loading also means that it is a less important source of strain accumulation compared to plate boundary faults. Without the fast and steady tectonic loading, mid-continental faults have more variable loading rates and are more susceptible to stress perturbations including those caused by ruptures of other faults and nontectonic stress changes, such as glacial isostatic adjustment or erosion. The slow and variable loading conditions on individual mid-continental faults yield long and highly variable recurrence times. Thus most mid-continental earthquakes are episodic with long periods of dormancy between earthquakes, and these large earthquakes seem to roam between widespread faults (Figure 2).

Nature, of course, is more complicated than depicted in the cartoon. Plate boundaries are usually zones of complex faults, and mid-continental faults and their loading conditions vary greatly between mid-continents and parts of a midcontinent (Mazzotti, 2007). In North China, for example, the Shanxi and Weihe rifts are major fault systems accommodating the eastward extrusion of the Asian continent, driven by the Indo-Asian 
collision (Tapponnier and Molnar, 1977; Tapponnier et al., 1982; Xu and Ma, 1992; Zhang et al., 2003). As such, their slip rates (2-4 mm/yr) are relatively steady and high by intraplate standards, so seismicity concentrated within the rift zone, and some quasiperiodicity may appear. Within the North China Plain, however, tectonic loading is shared by a complex system of faults on which slip rates are low $(<2 \mathrm{~mm} / \mathrm{yr})$ and perhaps variable. Hence large earthquakes roamed between distant faults. In the Central and Eastern U.S., which deforms even more slowly, faults often show clustered earthquakes for a while and then become dormant for thousands of years, such as the Meers Fault in Oklahoma (Crone et al., 2003). The New Madrid seismic zone, which experienced several large earthquakes in the past few thousand years including at least three $M \geq 6.8$ events in $1811-1812$, shows no significant surface deformation (Calais and Stein, 2009). Subsurface geology and the absence of significant topography indicate that the zone become active recently (Schweig and Ellis, 1994; Van Arsdale, 2000), perhaps in a cluster of large earthquakes (Holbrook et al., 2006). Hence the deformation rate must vary significantly over time and the recent cluster of large earthquakes may be ending (Calais and Stein, 2009; Liu et al., 2014b; Newman et al., 1999; Stein and Liu, 2009).

\subsection{Fault interaction between two faults}

In this conceptual model (Figure 9), fault interaction is key to understanding the spatiotemporal variability of mid-continental earthquakes. The best-known aspect of fault interaction is the change of static Coulomb stress by a fault rupture, which affects the stress state on nearby faults and may trigger earthquakes there (King et al., 1994; Li et al., 2005; Luo and Liu, 2010; Parsons et al., 2008; Pollitz and Sacks, 2002; Stein, 1999). In a 
complex fault system, a major rupture would change not only the static Coulomb stress but also the loading conditions of other faults. While the mechanics of such fault interaction remain poorly understood, fault interaction affects both fault evolution (Liu et al., 2010) and seismicity (Luo and Liu, 2010; Parsons et al., 2008), and long-term mechanical coupling between distant fault zones has been found in seismic and geological evidence from both plate boundary zones and mid-continents (Bennett et al., 2004; Dolan et al., 2007; Liu et al., 2011).

Luo and Liu (2012) studied a relatively simple two-fault system, the San Jacinto and San Andreas faults in southern California (Figure 10). Here the Pacific-North American relative plate motion is accommodated by the San Andreas and a number of subparallel faults, most importantly the San Jacinto Fault, which accommodates nearly as much of the relative plate motion as the San Andreas (Becker et al., 2005; Fialko, 2006; Meade and Hager, 2005). Geological slip rates on these two faults seem to have been complementary in the past few million years: increasing slip rates on one was accompanied by decreasing rates on the other (Bennett et al., 2004), indicating that these two faults are mechanically coupled. 

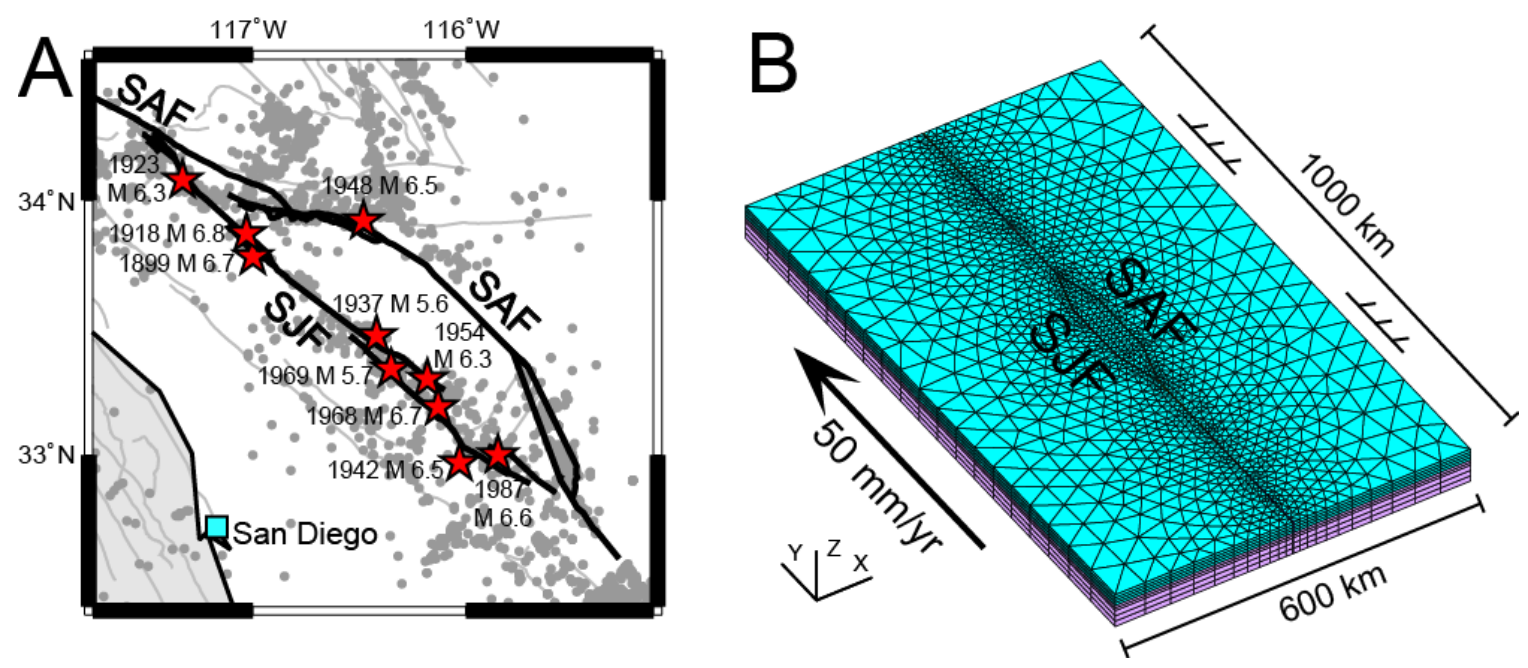

Figure 10. A. Faults and seismicity in southern California. Red stars show the moderate-sized earthquakes since 1899. Gray dots show $\mathrm{M}<5$ earthquakes since 1769. SAF: San Andreas Fault; SJF: San Jacinto Fault. B. Finite element model of the interaction between the San Andreas and San Jacinto Faults. (Luo and Liu, 2012).

Luo and Liu (2012) showed that earthquakes on either fault (nine M 6-7 events on the San Jacinto Fault and one on the southernmost San Andreas Fault since 1899) could change the static Coulomb stress on the other fault, as previously reported (Freed et al., 2007). However, over longer time scales mechanical coupling between these two faults goes beyond these individual events. When the San Jacinto Fault (SJF) stays locked, the loading rates on the San Andreas Fault increase by 40-80\% compared with the long-term average (Figure 11a). Conversely, when the SJF experiences clusters of large earthquakes, as in the past 200 years, the loading rate on the San Andreas decreases by a similar percentage (Figure 11b). 


\section{A. SJF locked $\quad$ B. SJF active}
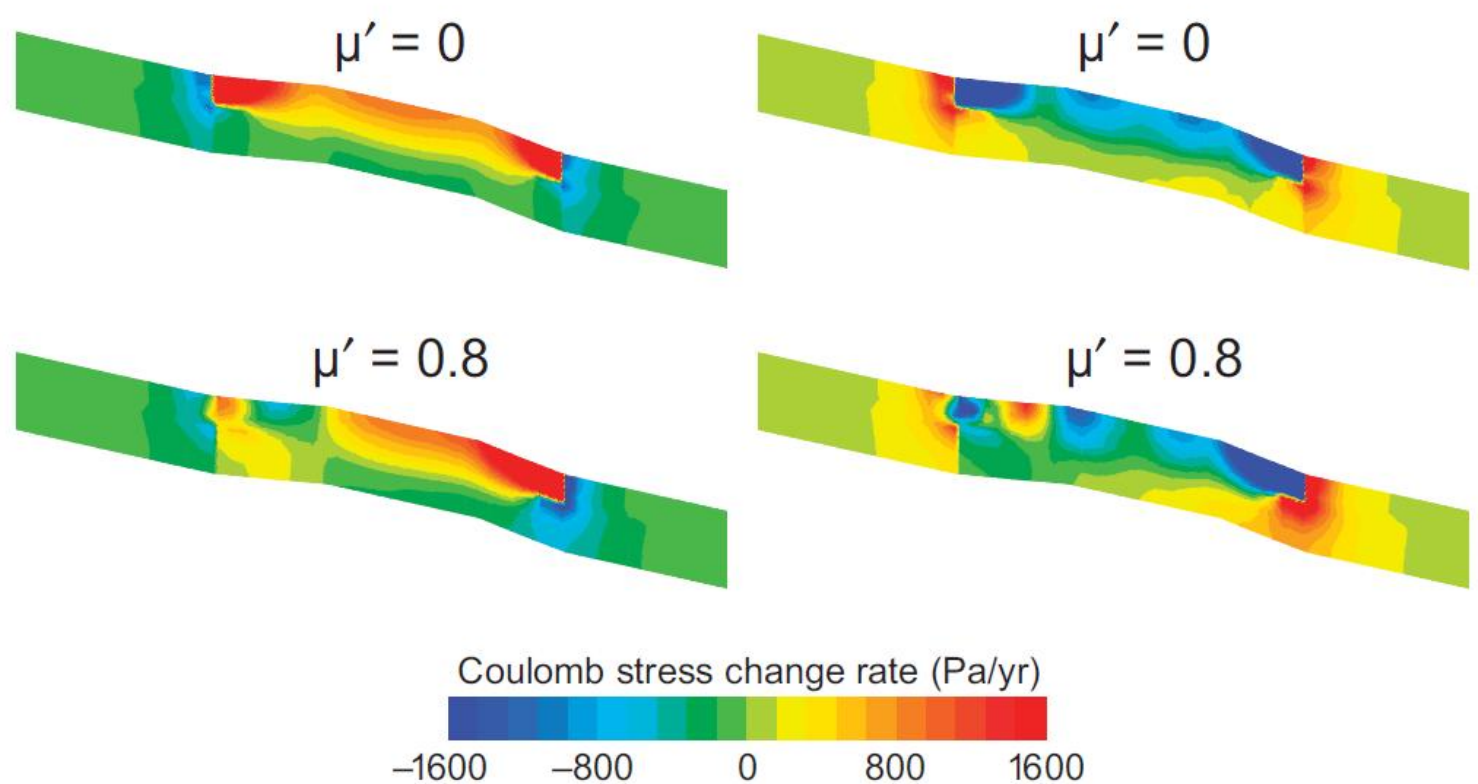

Figure 11. Predicted changes of stress rates on the southern San Andreas Fault relative to the long-term average when (A) the San Jacinto fault (SJF) is locked or (B) during a period of clustered earthquakes. (Luo and Liu, 2012).

The simulated long-term slip rates, averaged accumulative slip over many synthetic seismic cycles, are complementary to each other (Figure 12). Assuming the same fault properties, the model predicts similar long-term slip rates on the two faults, and that the sum of slip rates should be close to that on the unbifurcated parts of the San Andreas Fault (Figure 12a). If the San Jacinto Fault is assumed to be stronger than the San Andreas because it is younger, the long-term slip rate on the San Jacinto Fault decreases, causing an increase on the San Andreas Fault, so the total slip rates are still close to that on the unbifurcated San Andreas Fault (Figure 12b). These results are consistent with the observed complementary slip rates on the two faults over the past few million years 
(Bennett et al., 2004). The model predicts similar results for seismic moment release on these faults, consistent with the complementary moment release found on the different faults (Dolan et al., 2007).

Figure 12. Predicted steady-state long-term fault

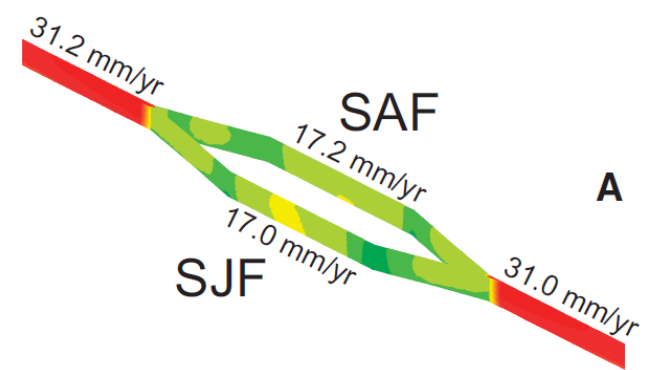
same fault properties for the two faults. B. Assuming a stronger San Jacinto fault. (Luo and Liu, 2012).

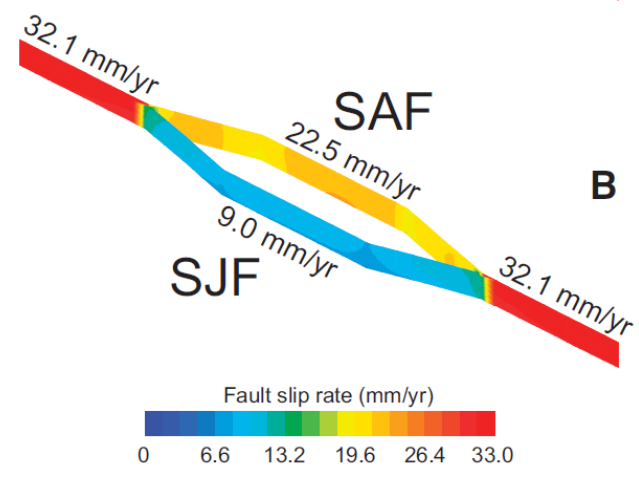

\subsection{Fault interaction in a complex dynamic system}

How the widespread faults in mid-continents interact over various timescales, however, remains poorly understood and hardly explored. Fault interactions, as illustrated conceptually in Figure 9, make mid-continental fault systems behave as a complex dynamic system (Stein et al., 2009). Because the underlying physics of such systems are unclear, most modeling efforts have been based on statistical physics approaches (Rundle et al., 2006; Rundle et al., 2003). The best-known of such studies are slider block models (Rundle and Jackson, 1977). In these models fault rupture is simulated by a block resting on a frictional surface and pulled by a spring; the stick-slip behavior of the block is 
predictable when the static friction is greater than the dynamic friction. Huang and Turcotte (1990) showed that interaction of two sliding blocks could lead the system to a deterministic chaos. A more complex system of distributed faults can be simulated by connecting many blocks in a two-dimensional array. How one block's sliding affects the rest of the system depends on the ratio of the stiffness of the pulling and blockconnecting springs, among other parameters (Rundle et al., 2003).

Li et al. (2009) used a simple finite element model to simulate the spatiotemporal behavior of mid-continent earthquakes. The model domain is an elastoplastic layer underlain by a viscous layer, loaded from the sides. The model plate is discretized into a grid, with a random perturbation of the frictional strength at the beginning of the simulation. When the Coulomb stress in a grid cell reaches the preset frictional strength, the cell fails (i.e., a synthetic earthquake), and stress in the cell drops by a prescribed amount. The stress drop at the failed cell changes the stress in the surrounding cells. Additional stress changes may derive from postseismic viscous relaxation in the lower, viscous layer. The coseismic and postseismic stress changes in the failed cells may increase (or decrease) stress in the neighboring regions, thus promoting (or inhibiting) earthquake occurrence there.

Despite its simplicity, this model predicts some complex spatiotemporal behaviors that are relevant to mid-continent earthquakes. For a plate that is laterally homogeneous (except for initially imposed random perturbations of crustal strength), the model predicts various spatiotemporal patterns of seismicity at different timescales: spatial clustering (in 
narrow belts) and scattering (across large regions) over hundreds of years, connected seismic belts over thousands of years, and seismicity scattering over the whole model region over tens of thousands of years. The orientation of the apparent seismic belts coincides with the optimal failure directions predicted by the imposed tectonic loading. Stress triggering and migration cause spatiotemporal clustering of earthquakes (Figure 13a). When preexisting fault zones (weak zones) are included in the model, seismicity initiates within the weak zones but then extends far beyond them (Figure 13b). If a fault is weakened following a large earthquake, earthquakes may repeat on the same fault in the absence of strong tectonic loading. These results suggest that the long-term seismicity in mid-continents can be quite different from that inferred from short earthquake catalogs, and mid-continental earthquakes may not be limited to specific fault zones even if they are weaker than other faults. 

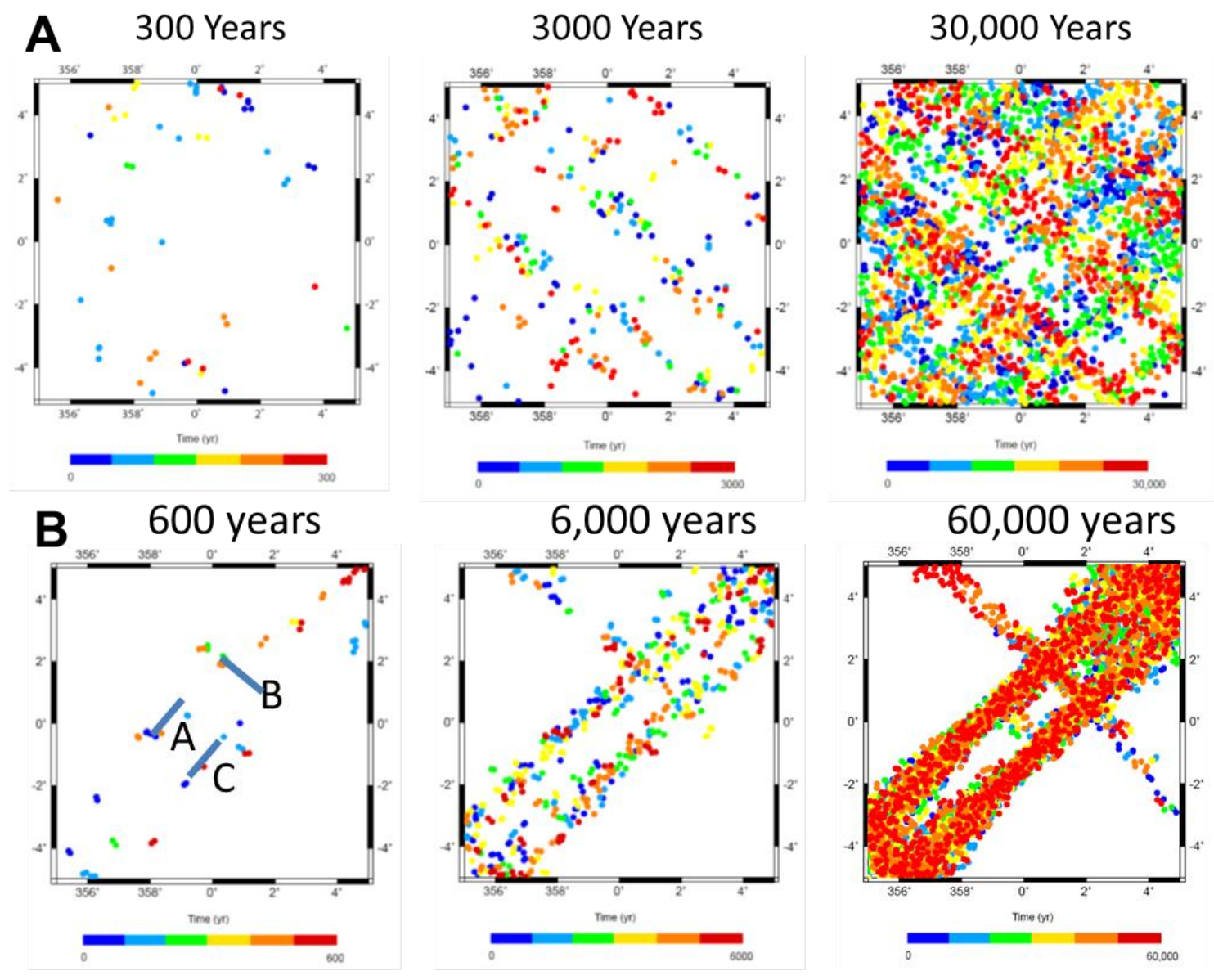

Figure 13. A. Simulated earthquakes (colored dots) in a laterally homogeneous (except for an initial random perturbation of the crustal strength) in various time windows. The color bars indicate time since the beginning of the simulation. The model domain is $2000 \times 2000 \mathrm{~km}$ and 60 $\mathrm{km}$ thick, loaded by $1 \mathrm{~mm} / \mathrm{yr}$ compression on the E-W sides and extension on the N-S sides. B. Same as in (a) except with three preexisting weak zones (short bars marked A, B, and C in the left panel). (Li et al., 2009).

\section{MID-CONTINENT EARTHQUAKES: SPATIOTEMPORAL VARIABILITY}

Because intraplate continental faults are loaded slowly and collectively by far-field tectonic stress, the loading conditions on each individual fault vary with many additional 
factors including ruptures on other faults and nontectonic stress perturbations. Thus regular, or even quasi-regular, recurrence times should not be expected. The temporal rupture patterns on individual fault zones in Australia (Clark et al., 2012) resemble Devil's Staircase functions (Figure 14) - clusters of activity separated by long and irregular intervals of quiescence. Evidence for similar temporal patterns has been found in the central and eastern US (Holbrook et al., 2006) and in North China (Xu and Deng, 1996a). Clearly, for earthquakes with a Devil's Staircase evolution, the probability of events in a future time window is quite different from that of periodic events (Simkin and Roychowdhury, 2014).

A Devil's Staircase is a fractal and a property of chaotic dynamic systems (Devaney et al., 1989; Turcotte, 1997). The apparent long-distance roaming of large midcontinental earthquakes also suggests dynamic system behavior. In such a system, change of any part of the system (such as rupture of a fault) could impact nonlinearly the behavior of the whole system, so the concepts of seismic cycles and recurrence intervals often used on plate boundaries may not apply in mid-continents. 

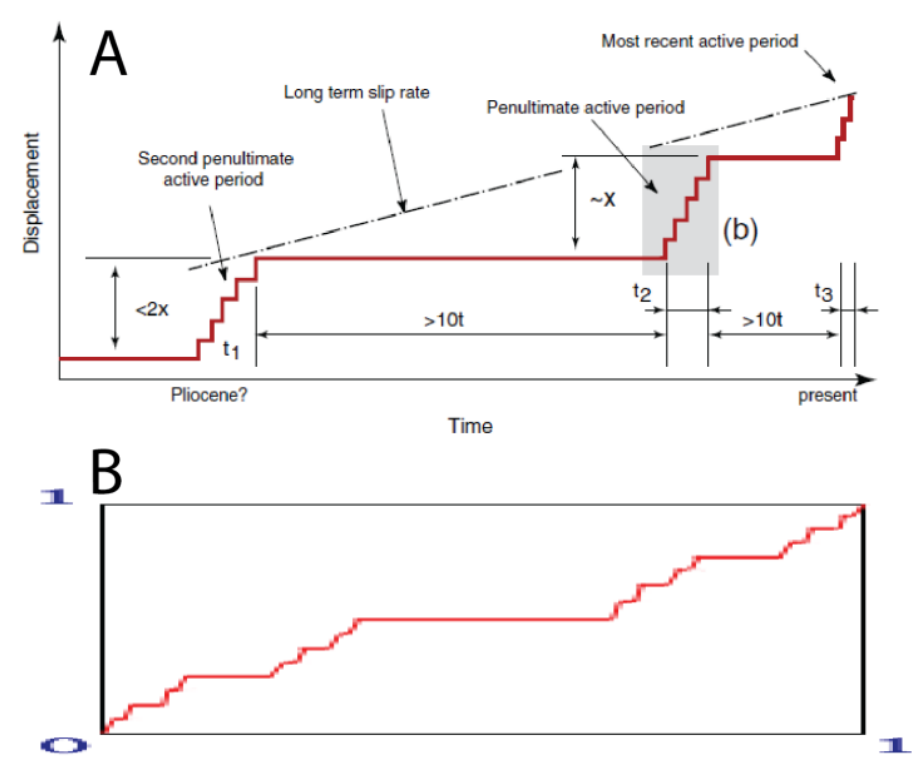

Figure 14. A. Generalized fault slip history for Australian stable continental region faults (Clark et al., 2012). B. A typical Devil's Staircase function (http:// www.math.hmc.edu/funfacts/).

To understand how the dynamic system concept affects our view of mid-continental earthquakes, a brief review of the basic models of earthquakes may be helpful. Current understanding of earthquake physics is based on the elastic rebound model, proposed by Reid (1910) following the 1906 San Francisco earthquake. In this model the relative crustal motion across a fault gradually accumulates stress on the frictionally locked fault plane until some critical value is reached, at which point the fault ruptures in an earthquake, stress on the fault drops, and the strained crust near the fault plane springs back (elastic rebound). With time, the process repeats.

Plate tectonics, recognized nearly half a century later, provides the driving mechanism in the elastic rebound model. Relative plate motion steadily loads the plate 
boundary faults. Assuming from time to time an entire fault segment ruptures (the characteristic earthquake model) (Schwartz and Coppersmith, 1984), and that the rupture drops stress uniformly along the fault segment to some background value, then the steady loading would lead to periodic or quasi-periodic earthquake recurrences. Thus the time of a previous characteristic earthquake relative to the recurrence interval on a given fault segment allows estimates of the probability of rupture in a future time window. If a fault segment has not ruptured in a seemingly long time (a seismic gap), it should be most likely to rupture in the future (Nishenko, 1991).

These ideas are intuitively appealing, and in many cases are helpful in assessing earthquake hazards. However, exceptions are abundant, even on plate boundary faults (Jackson and Kagan, 2006; Kagan, 1993; Rong et al., 2003). The segmentation of faults, presumably caused by changes of fault geometry (bends or stepovers), variations in lithology, or intersections with other faults, often produces unexpected behavior. The 1992 Landers earthquake ( $M w$ 7.3) ruptured across previously defined segment boundaries and jumped through a number of different faults (Wald and Heaton, 1994). Similar behavior occurred in the 2008 Wenchuan earthquake in China (Xu et al., 2009) and the 2011 Tohoku earthquake (Mw 9.2) in Japan (Stein et al., 2012), among many other examples. The uncertain consequences of fault segmentation make it difficult to define characteristic earthquakes and the related concept of recurrence intervals (Jackson and Kagan, 2006; Kagan, 1993). The concept of characteristic earthquakes was based on the rupture history of the San Andreas Fault in the Carrizo Plain, California. The 1857 Fort Tejon earthquake ruptured this part of the San Andreas, and similar ruptures before 
it were inferred from paleoseismic evidence (Schwartz and Coppersmith, 1984; Sieh and Jahns, 1984). Recent high-resolution geomorphic and paleoseismic data (Ludwig et al., 2010; Scharer, 2010; Zielke et al., 2010), however, have shown that the rupture patterns do not fit the characteristic earthquake model, but are more complicated with variable rupture lengths and locations (Figure 15).

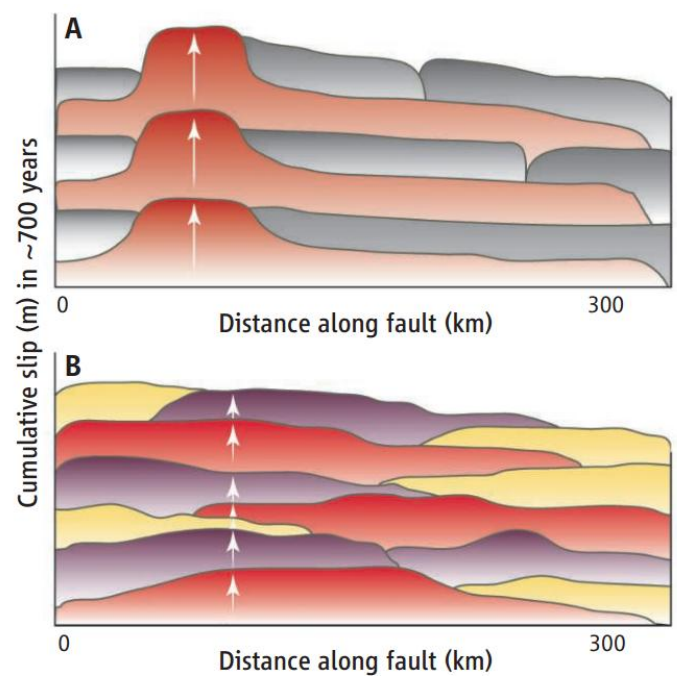

Figure 15. A. Characteristic earthquake model, in which characteristic large ruptures break the entire fault segment. Arrows highlight slip-per-earthquake at the same location along the fault. Each shape shows the distribution of slip along the fault in an individual earthquake, and each successive earthquake adds slip over time. B. Variable slip model suggested by recent studies combing high-resolution geomorphology and dating in the Carrizo Plain, where the 1857 Fort Tejon earthquake ruptured. (Scharer, 2010).

The problems with these concepts are amplified in mid-continents. Fault segmentation is hard to define, and in many places large earthquakes occurred on faults that were previously unknown or were not considered active (Clark et al., 2014; Liu et al., 
2014c). Even on well-defined and seismically active faults, the slow and variable loading means that no regular recurrence intervals may be expected. The earthquake sequence in the New Madrid area, which include events around 1450 and 900 thought to have been similar to the 1811-1812 events, is inferred from liquefaction data (Tuttle et al., 2002). Even if this interpretation survives future analysis, these repeated NMSZ earthquakes are unusual for, rather than the norm of, mid-continental earthquakes, and large earthquakes have occurred outside the New Madrid fault zones defined by current seismicity (Figure 7) (Cox et al., 2010; Holbrook et al., 2006; Tuttle, 2009).

\section{IMPLICATIONS FOR HAZARD ASSESSMENT}

Earthquake hazard assessment is a challenging enterprise, involving assumptions about four key questions: 1) Where will large earthquakes occur? 2) When will large earthquakes occur? 3) How large will they be? and 4) How strong will the shaking be? Answering these questions requires knowledge of many key parameters that are often poorly constrained (Peresan et al., 2005; Stein et al., 2012) and in some cases hard to better constrain (Stein and Friedrich, 2014), especially in mid-continents.

\subsection{Where?}

The locations of previous large earthquakes are assumed to indicate where future large earthquakes will occur, but the earthquake record is almost always too short to reliably establish the spatiotemporal pattern of large earthquake occurrence. The challenge is illustrated by recent large earthquakes in Japan (Geller, 2011), North Africa 
(Swafford and Stein, 2007), Italy (Stein et al., 2015a), and Haiti (Manaker et al., 2008) that occurred in places mapped as relatively safe. Many of these "misses" happened at plate boundaries, where we have reasonable knowledge of the boundary geometry, and thus some ideas of "where", so the surprises were mainly the size of these earthquakes. For mid-continental earthquakes, we are often surprised by where they occur.

This problem is shown by the hazard map for North China and surrounding regions (Figure 16). Almost all the areas mapped as having high hazard are where recent large earthquakes occurred, but using this approach prior to these events would have missed them. The 2008 Wenchuan earthquake (Mw 8.9), for example, ruptured the Longmenshan Fault that has had limited instrumentally recorded seismicity and no destructive earthquakes in the past millennium (Ran et al., 2010). Its slip rate is less than $3 \mathrm{~mm} / \mathrm{yr}$ (Shen et al., 2009), almost an order of magnitude lower than those on some of the neighboring faults. As a result, the Longmenshan Fault was assigned low hazard in this 1999 map. In the North China Plain a high level of hazard is assigned around the epicenters of recent large events, but no previous large earthquakes occurred in these areas in the past two thousand years (Ming et al., 1995), and no evidence of abnormal fault activity has been found in these regions (Liu et al., 2014c). The epicentral region of the 1668 Tancheng earthquake (M 8.5), the largest event in the Chinese catalog, would also have been missed because the hosting Tanlu Fault, a major Mesozoic tectonic structure, is largely inactive through the Cenozoic. GPS data show less than $1 \mathrm{~mm} / \mathrm{yr}$ of fault slip (Liu et al., 2014c; Shen et al., 2000). 


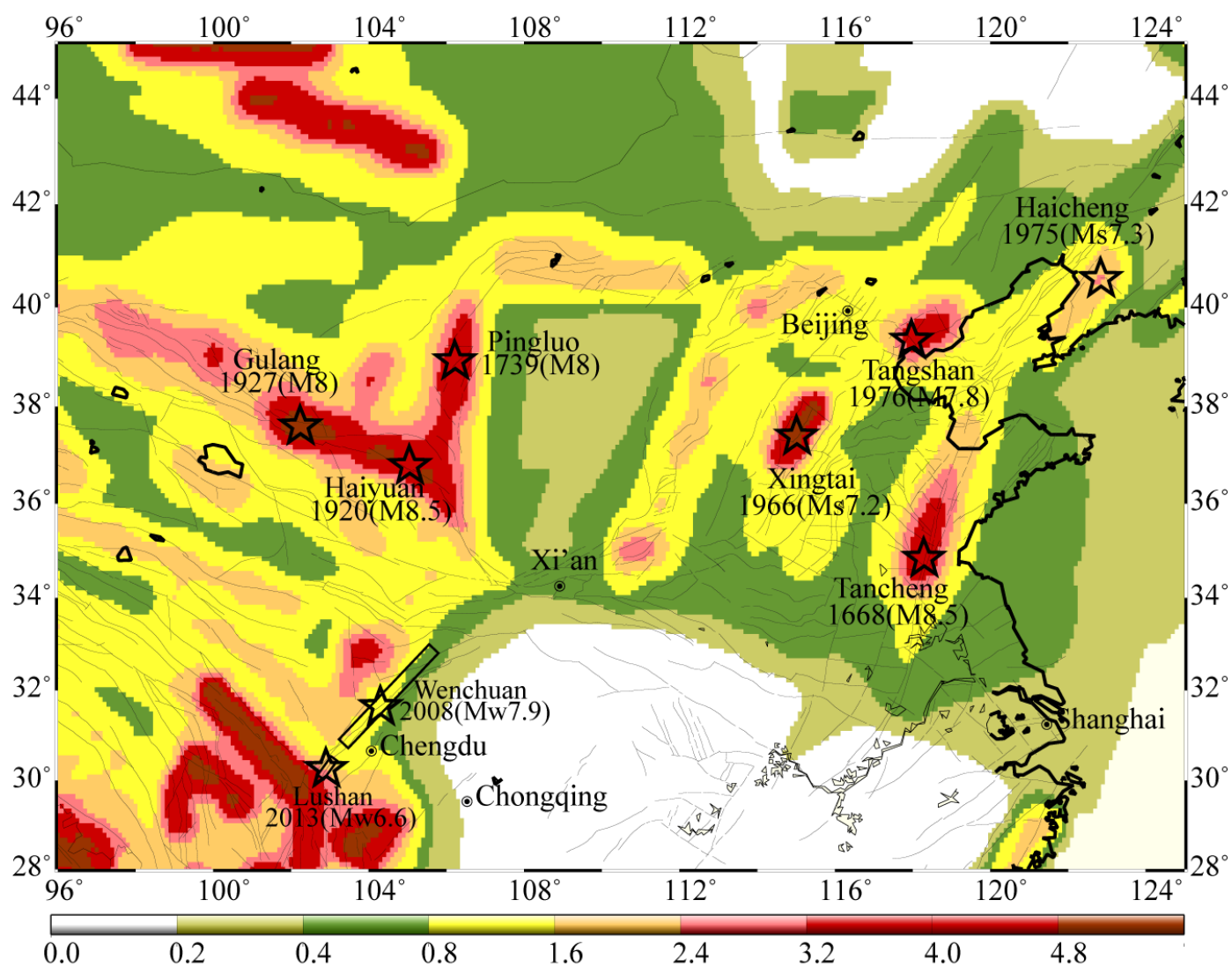

Figure 16. Seismic hazard map for North China and surrounding regions made in 1999 (GSHAP, 1999: http://www.seismo.ethz.ch/static/GSHAP). The hazard is expressed as the peak ground acceleration $(P G A)$ on firm rock, in $\mathrm{m} / \mathrm{s}^{2}$, expected to be exceeded in the next 50 years with a probability of $10 \%$. Stars indicate the epicenters of recent large earthquakes. The box shows the rupture zone of the 2008 Wenchuan earthquake (Mw 7.9), which is mapped as low hazard. (Liu et al., 2014c).

Because large earthquakes in mid-continents tend to roam between widespread fault systems, previous large earthquakes may not be a good indicator of where future large earthquakes will occur. Moreover, because many mid-continental faults have been accumulating strain for thousands of years that may eventually be released by a large 
earthquake, low slip rates on these faults does not mean they are safe, and the absence of known previous large earthquakes does not mean no large earthquakes will occur there in the future. Because it should take thousands of years or longer for these fault zones to accumulate enough strain energy for a large earthquake, faults where large earthquakes occurred in the recent past may not necessarily be more dangerous than other places.

\subsection{When?}

When to expect an earthquake is related to where to expect one, as the discussion of the spatiotemporal pattern of large earthquake occurrence indicates. The Devil's Staircase temporal pattern of mid-continental earthquakes would invalidate probability estimates based on recurrence interval models. Even if a recurrence interval can be established for a specific fault, quite different probability estimates and hence hazard maps result from assuming either a constant probability of a major earthquake within the remaining time window of a recurrence interval, or a variable probability that increases with time (Hebden and Stein, 2009). This effect makes it difficult to talk except in generalities about "the" probability of an earthquake (Savage, 1991; Stark and Freedman, 2003). In intraplate settings the problem is acute, because earthquakes on a specific fault can "turn on" for a while and "shut down" for a longer time, so it is hard to say whether to expect earthquakes to continue on a recently-active fault. If the temporal pattern of earthquakes on a fault resembles a Devil's Staircase function (Figure 14), the probability of an earthquake in some future time window would be quite different from that one would infer assuming regular recurrence intervals. 
Another difficulty in mid-continents is that long sequences of aftershocks sometimes occur (Stein and Liu, 2009). Because small earthquakes are often regarded as signs of stress building up toward the next big earthquake, small earthquakes in the source regions of previous large earthquakes often cause alarms. One example is the sequence of earthquakes in the Tangshan region of North China in 2012, which includes several M 4 4.8 events. These earthquakes caused much concern and heated debate: are they aftershocks of the great 1976 earthquake, or harbingers of a new period of active seismicity in Tangshan and the rest of North China, where seismic activity seems to fluctuate between highs and lows over a few decades (Ma, 1989)?

Aftershocks are a sequence of earthquakes that follow a main shock. Their magnitude and frequency typically decay with time to a lower, 'normal' level of background seismicity (Liu and Stein, 2011). Empirically they follow the Omori law of decay (Omori, 1894). Aftershock sequences of large interplate earthquakes usually end a few years after the main shock (Parsons, 2002), but in diffuse plate boundary zones and mid-continents, some aftershock sequences seem to last much longer (Ebel et al., 2000; Stein and Liu, 2009). The ending of the aftershock sequences is difficult to identify precisely, because selecting the area to define as the aftershock zone can be subjective, the background seismicity may fluctuate, and for many recent large intracontinental earthquakes, the background seismicity before the main shock cannot be established.

The multiple datasets available for Tangshan allowed Liu and Wang (2012) to show that recent seismicity there is most likely aftershocks of the large 1976 earthquake 
(Figure 17a): (1) A regional seismic network operated since 1970, giving a six-year record before the 1976 main shock to serve as a reference for background seismicity (Figure 17b); (2) Earthquakes since the main shock follow the Omori decay law (Figure 17c). (3) The seismicity rates of the Tangshan, Xingtai, and Haicheng regions during 1986 - 2010 (10 years after the Tangshan earthquake and 20 years after the Xingtai earthquake) are clearly higher than the average for the North China Plain (Figure 17d). Hence either these regions are tectonically more active than the rest of the North China Plain, or the seismicity are aftershocks of the large earthquakes decades ago. Because these regions showed no sign of abnormal tectonic activity before the large earthquakes, aftershocks are more likely the cause. (4) Strain rates calculated from GPS data are higher in the Tangshan and Xingtai regions than in the rest of the North China Plain (Fig 17e). Again, because these regions have no evidence of unusually high tectonic activity relative to other fault zones in the North China Plain, the higher strain rates indicate that postseismic deformation continues at present (the Haicheng region does not have sufficient GPS stations to allow a meaningful strain rate calculation). The seismicity in the Tangshan region thus shows that large mid-continental earthquakes can have aftershock sequences much longer than that for typical interplate earthquakes. Whether to interpret small earthquakes as aftershocks or precursors provides another challenge for hazard assessment in mid-continents. 

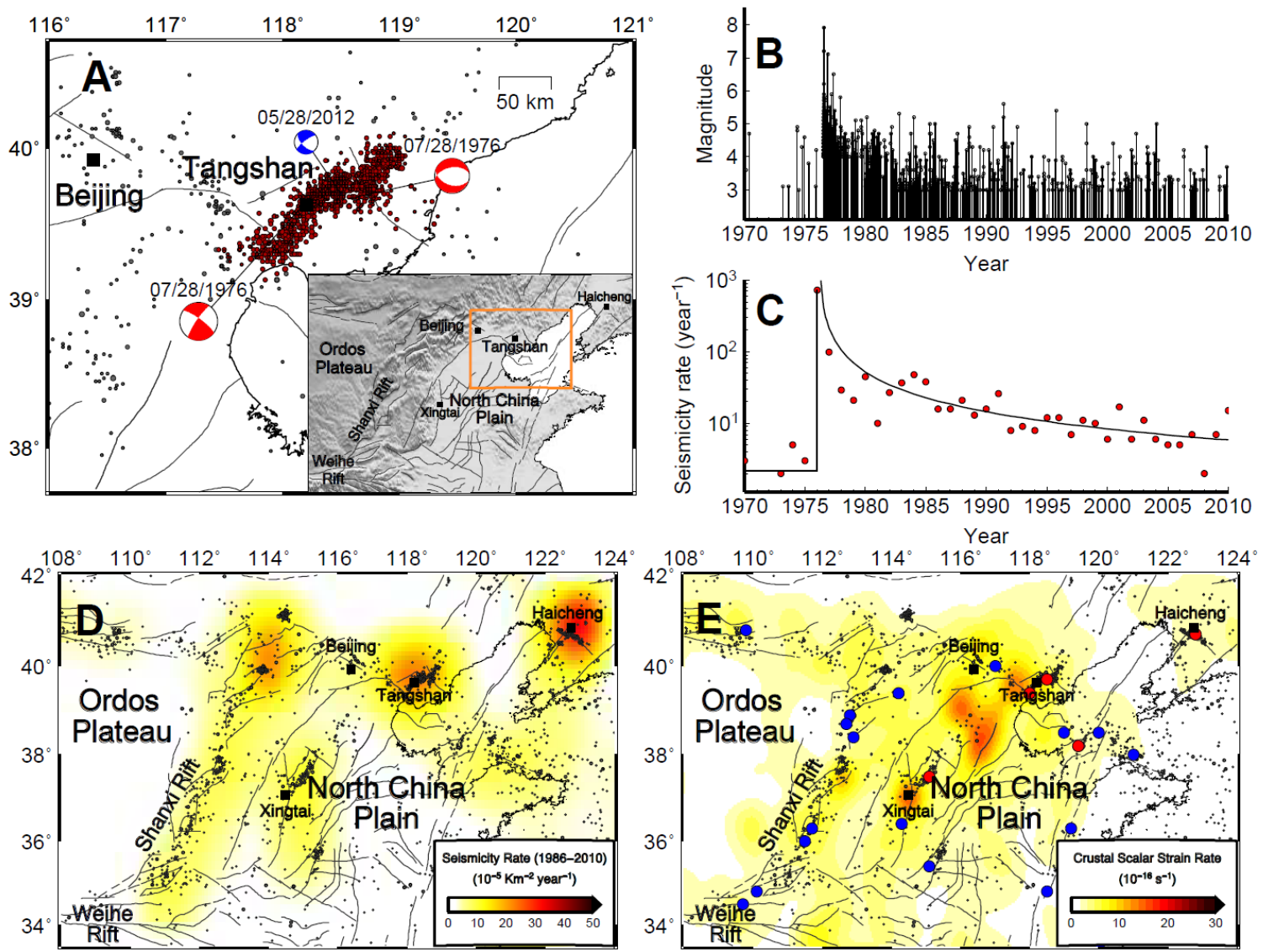

Figure 17. A. Seismicity in the source region of the 1976 Tangshan earthquake. Red dots are epicenters of aftershocks; black dots are background seismicity ( $M \geq 3.0,1970-2011)$. The focal mechanism solutions are for the two main shocks of 1976 and the May 5, 2012 event. The inset map shows the location of the Tangshan region. B. Earthquake sequence in the source region of the great Tangshan earthquake since 1970. C.Seismicity rates (number of events per year) of the Tangshan earthquake sequence. Solid lines are least-square fitting. D. Color contours of seismicity rates in North China. E. Scalar strain rates in North China. Blue dots are epicenters of large historic earthquakes; red dots are instrumentally recorded large earthquakes. (Liu and Wang, 2012). 
Another process in mid-continents similar to the long sequences of aftershocks is releasing of pre-stored elastic energy by a sequence of earthquakes. This process is probably the cause of the current earthquake sequence in the New Madrid seismic zone (NMSZ) (Figure 18a). The inconsistency between the repeated large earthquakes in the past millennium (Tuttle et al., 2002) and the lack of strain accumulation across the New Madrid fault zone (Calais and Stein, 2009; Newman et al., 1999) may be explained if the current earthquake sequence resulted from recent fault reactivation (Schweig and Ellis, 1994), releasing elastic strain energy previously stored in the crust. Proposed triggers for this reactivation include stress perturbation due to erosional-depositional processes (Calais et al., 2010), or glacial isostatic adjustment (Grollimund and Zoback, 2001) together with recent local weakening of the crust (Kenner and Segall, 2000; McKenna et al., 2007).
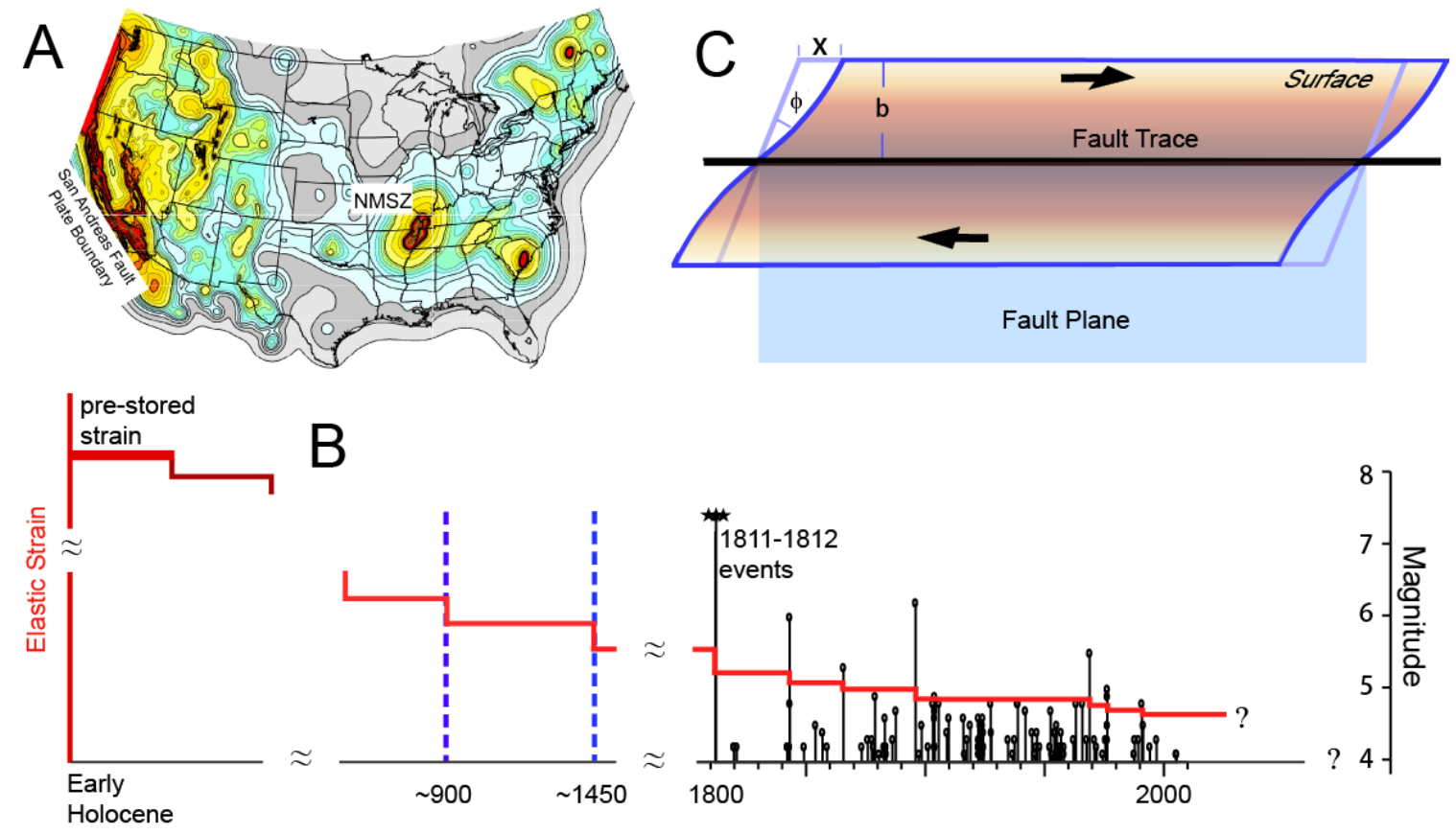
Figure 18. (a) U.S. Geological Survey earthquake hazard map showing the New Madrid seismic zone (NMSZ) with hazard comparable to California's, based on assumption that large earthquakes continue in the NMSZ. (b) Conceptual model of a decaying NMSZ earthquake sequence, showing large earthquakes during 1811-1812, similar events around 900 and 1450 AD, and smaller events since 1812. (c) Simple model for strain accumulation on a strike-slip fault. (Liu et al., 2014b).

If the current NMSZ seismicity mainly releases pre-stored strain energy in the crust, it is analogous to an aftershock sequence in that the rate of energy release is decaying with time. Thus, in contrast to the repeated earthquakes at plate boundaries, this sequence of earthquakes will eventually end (Figure 18b). The amount of pre-stored strain energy limits how long the earthquake sequence can last. Some estimates may be derived from a simple model of a strike-slip fault on which strain energy accumulates due to relative motion across the fault when it stays locked (Figure 18c.). The elastic strain $(\varepsilon)$ is measured by the angle $\phi$ between a line initially perpendicular to the fault trace and its current location due to shearing: $\varepsilon=\tan \phi=x / b$, where $b$ is the half-width of the fault zone and $x$ is the displacement in far field, which is a measure of the cumulative fault slip needed to completely release the elastic strain. The total strain that can be stored is limited by the yielding shear stress on the fault: $\tau_{\max }=G \varepsilon=G x / b$, where $\mathrm{G}$ is the shear modulus.

The values of $b$ and $G$ are relatively well constrained (Hough and Page, 2011). The value of $\tau_{\max }$ should be higher than the stress drops during large earthquakes, typically a 
few MPa, because it is the yielding shear stress on the fault prior to its reactivation. Taking $\tau_{\max }=20 \mathrm{MPa}$, the value of the maximum tectonic shear stress in unfaulted crust in many places (McGarr and Gay, 1978) and hence likely an upper limit, $b=50 \mathrm{~km}$, and $G=30 \mathrm{GPa}$, yields $x=33 \mathrm{~m}$. This is the total slip on the fault needed to completely release the stored strain. For a sequence of earthquakes 500 years apart with $2 \mathrm{~m}$ of seismic slip each, the stored strain can produce 17 events and the sequence would last 8000 years. A similar sequence of larger events with greater slip would end sooner. Furthermore, the release of pre-stored strain should follow a decay pattern like Omori's law for aftershocks, with more energy released during early stages. If so, the sequence should be shorter than these estimates.

\subsection{How large?}

Another important issue for hazard assessment involves choosing Mmax, the magnitude of the largest earthquake to expect. This is challenging even for plate boundaries, as illustrated by the fact that the 2011 Tohoku earthquake was much larger than anticipated (Stein and Okal, 2011). For intraplate areas, the challenge is even greater for two reasons. First, because seismicity rates are low and the records are short, it is likely that we have not observed the largest earthquake. For example, in the Lower Rhine Embayment (Figure 19a), should the largest known earthquake be regarded as the biggest that can occur in the area, or simply the largest in the past 650 years spanned by the catalog? The largest known earthquake had magnitude $\sim 5.7$ and should occur on average about every 400 years. Extrapolating the line predicts that a magnitude 7.3 earthquake 
would occur on average about every 10,000 years, assuming such large earthquakes actually occur.

Numerical simulations (Figure 19b) illustrate that the larger magnitude earthquake appearing in a catalog is likely to be that with mean recurrence time equal to the catalog length. Even if the actual maximum magnitude is much larger, it is unlikely to be observed. Because catalogs are often short relative to the average recurrence time of large earthquakes, larger earthquakes than anticipated could occur.
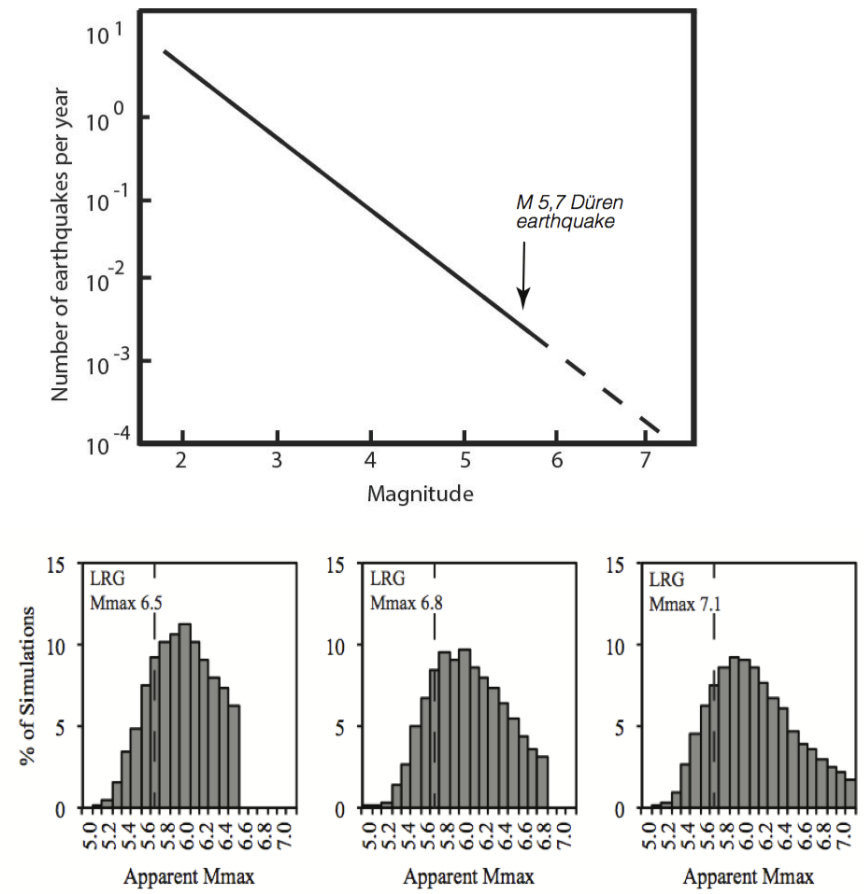

Figure 19. A. (top): Earthquake frequency-magnitude data for the Lower Rhine Embayment (Vanneste et al. 2013). B. (bottom): Histograms of the largest earthquake "observed" in a set of 700-year-old synthetic catalogs computed for the observed frequency-magnitude curve shown, 
for three different maximum magnitudes. Regardless of the catalog's Mmax value, the most likely "observed" value is about 6.0. (Merino, 2014).

The maximum magnitude assumed may not matter much for designing ordinary structures. A map with a 475 year return period, which predicts that the mapped ground motion has a $10 \%$ chance being exceeded in 50 years, does not depend strongly on the assumed maximum magnitude (Figure 20). However, the choice of maximum magnitude is crucial for critical facilities like nuclear power plants that are designed to withstand the maximum shaking expected at low annual probability or equivalently in a very long interval, 10,000 years.

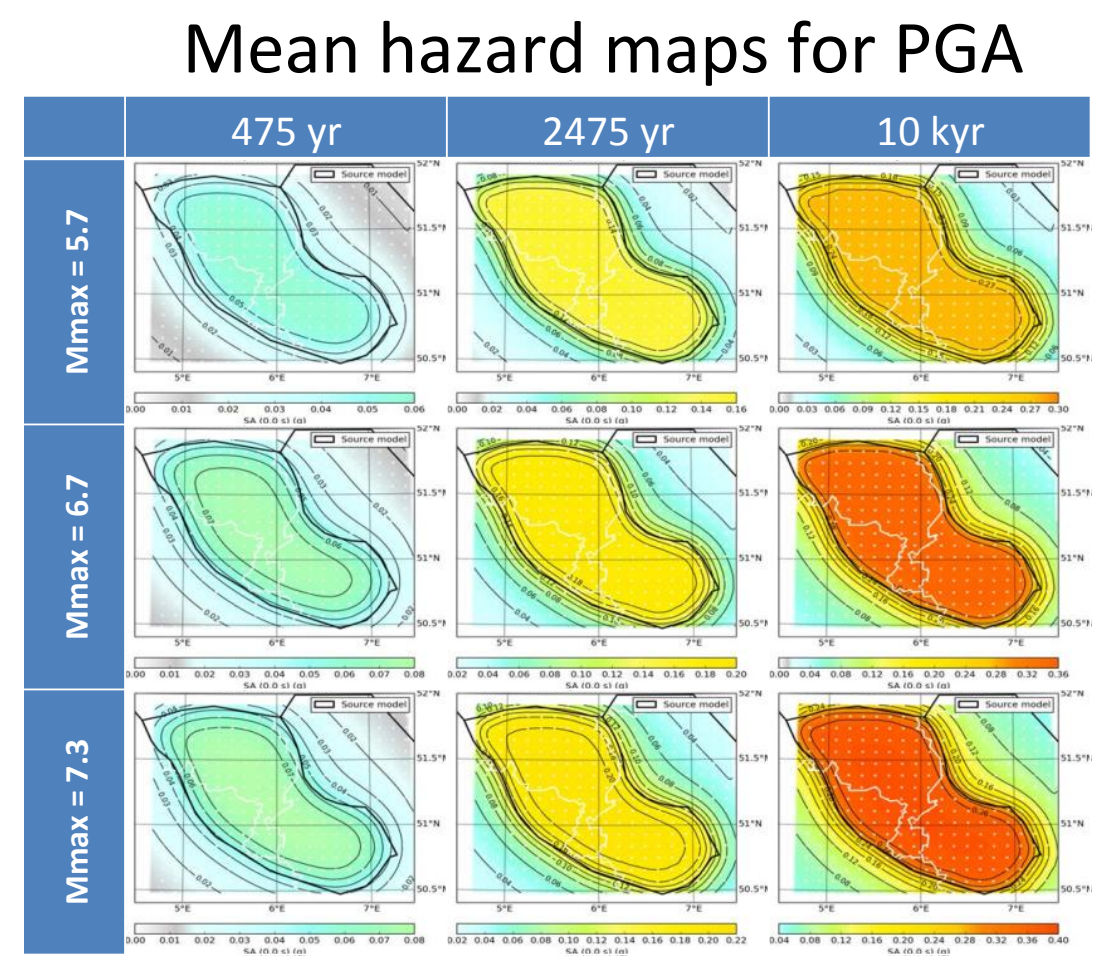

Figure 20. Comparison of hazard maps of the Lower Rhine Embayment for three different return periods (columns) and three different maximum magnitudes (rows). (Vanneste et al., 2013). 
This discussion is based on the assumption of a defined recurrence time for sizelimiting (characteristic) earthquakes. As we have shown, these models have been questioned and are especially problematic in mid-continents where interacting faults form complex dynamic systems and the resulting earthquakes have strong spatiotemporal variability. Thus inferences from the recent past can be quite misleading, because future earthquake occurrence may be very different.

\subsection{How strong will shaking be?}

Hazard mapping also has to assume how much shaking future earthquakes will produce. This involves adopting a ground motion prediction equation (GMPE), which predicts the ground motion expected at a given distance from earthquakes of a given size. At plate boundaries, shaking observations from prior large earthquakes provide data for GMPEs. However, in intraplate areas, instrumental data for large earthquakes are often lacking, because large earthquakes are rarer. Without good constraining data, the predicted hazard depends significantly on the GMPE assumed. For example, in mapping the hazard for the New Madrid seismic zone, Frankel et al. (1996) state that "workshop participants were not comfortable" with the source model used in an existing ground motion relation, and so "decided to construct" a new relation, which predicted much higher ground motions.

The shaking predicted by a hazard map reflects a partial trade-off between the choices of maximum magnitude and GMPE. Figure 21 illustrates this effect with four possible 
maps for the New Madrid zone. The two in each row are for the same GMPE, but different values of Mmax - the magnitude of the largest earthquake on the main faults. Raising this magnitude from 7 to 8 increases the predicted hazard at St. Louis by about $35 \%$. For Memphis, which is closer to the main faults, the increase is even greater. This is because the assumed Mmax of the largest earthquake on the main faults affects the predicted hazard especially near those faults. The two maps in each column have the same Mmax but different ground motion models. The Frankel et al. (1996) GMPE predicts a hazard in St. Louis about $80 \%$ higher than that predicted by the Toro et al. (1997) model. For Memphis, this increase is about 30\%. The ground motion model affects the predicted hazard all over the area, because shaking results both from the largest earthquakes and from smaller earthquakes off the main faults. 


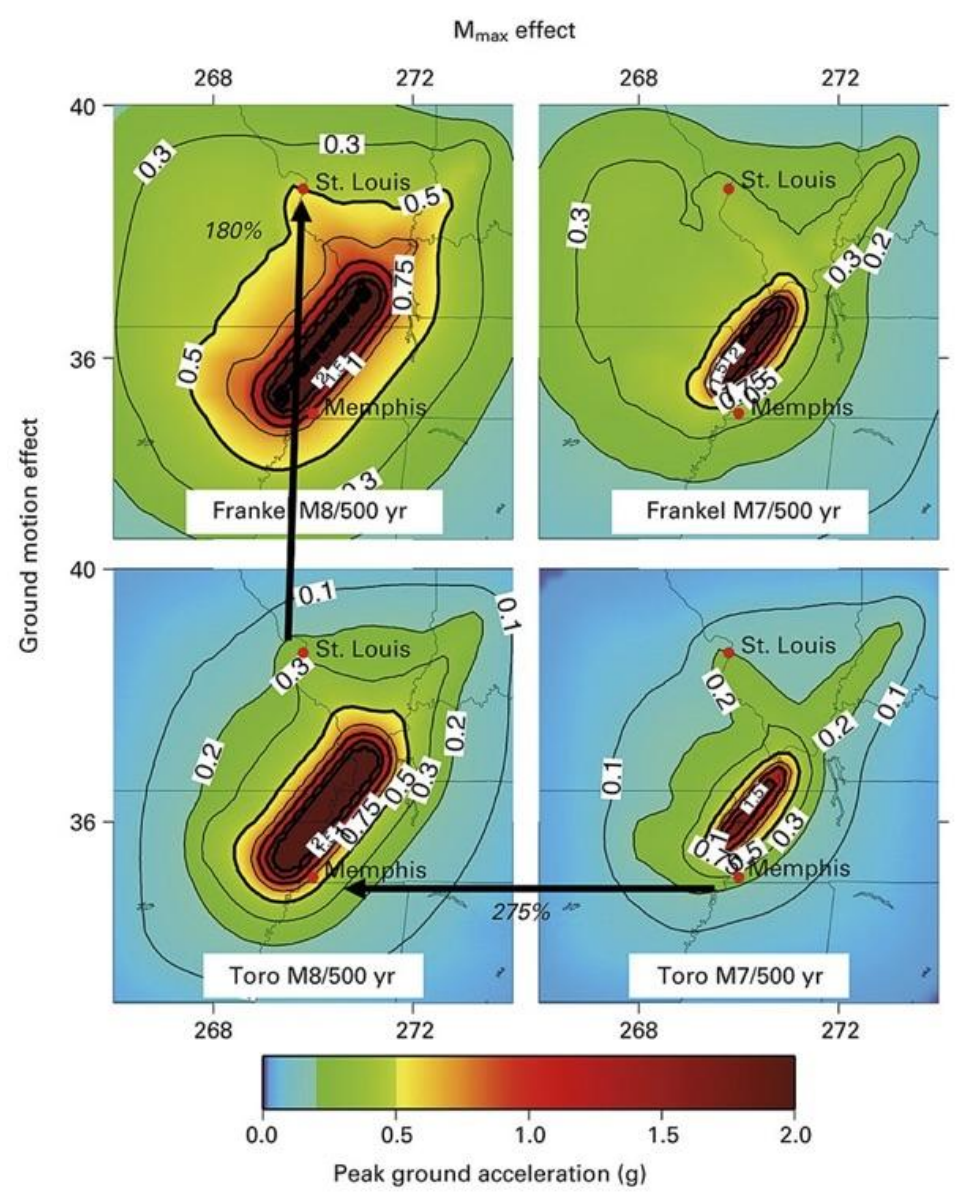

Figure 21. Comparison of different hazard maps ( $2 \%$ probability in 50 years) for the New Madrid seismic zone (Newman et al., 2001).

\section{DISCUSSION}

The elastic rebound theory, and later the plate tectonic theory, have led many to believe that the time of future fault ruptures and hence large earthquakes can be determined if we know the initial conditions and can measure the fault strength and tectonic loading rates. Advances in space-based geodesy now permit precise measurements of strain rates across faults that may be converted to stressing (loading) rates, and earthquake history may provide some constraints on the "initial" conditions. 
Yet fault ruptures in nature have not followed the scripts of a deterministic system: earthquake prediction remains an unreachable goal (Geller et al., 1997), and earthquake hazard assessment, taking into consideration of the uncertainties of key parameters and being based on probability theory, has met with mixed results (Stein and Friedrich, 2014).

The story is not new. Since Henri Poincaré's famous attempt to solve the three-body problem in 1887 , it has been realized that nonlinearity in deterministic systems could lead to divergent evolution paths from small perturbations of the initial state (the butterfly effect). This behavior is known as deterministic chaos (Lorenz, 1963). Deterministic chaos characterizes complex dynamic systems - "dynamic" in the sense that the parts (particles) of the system follow a set of deterministic rules, for example Newtonian mechanics, in their temporal evolution, and "complex" because the nonlinearity and interactions of individual parts make full prediction of the system's state at a given future time impossible (Zeigler et al., 2000).

Complex dynamic systems are common in nature. Given the heterogeneities at all scales in the lithosphere, from mineral grains to tectonic plates, and the multiple physical and chemical processes involved in fault ruptures, it seems plausible that fault systems, either in continental interiors or in plate boundary zones, should behave as complex systems (Kanamori and Brodsky, 2004; Keilis-Borok, 1990; Turcotte, 1997; Turcotte and Malamud, 2002). The Gutenberg-Richter power law of the frequency-magnitude relation of earthquakes, followed by both interplate and intraplate earthquakes, is characteristic of complex systems (Turcotte, 1997). In this review we attribute the spatiotemporal 
variability of large mid-continent earthquakes to the behavior of complex dynamic systems. Recognizing that mid-continental faults act this way does not directly make hazard assessment easier, but leads to an important, and necessary, paradigm shift. In mid-continents one cannot isolate any fault or fault segment from the rest of the system and consider only its rupture and loading history (although it is debatable whether such approaches can be even applied in plate boundary zones). Instead we need to better understand the behavior of the entire system. This is challenging, and as for most complex dynamic systems, the best we can hope is to understand the qualitative behavior of the system, rather than to obtain precise solutions for the system's evolution (Strogatz, 2014). For mid-continental earthquakes, we are further limited by many parameters that are poorly known, unknown, or simply unknowable (Stein et al., 2011).

This view may appear pessimistic, but is actually not. Most researchers and national research programs have long ago given up seeking "precise solutions", i.e., short-term earthquake predictions (Geller et al., 1997). Instead, effort has been directed toward longterm forecasting and probabilistic hazard assessment, which would greatly benefit from better understanding of the qualitative behavior of the system of interacting faults in midcontinents. This requires learning how the faults interact with each other over various timescales and how such interactions affect the system's behavior. Experiments with arrays of slider blocks (Rundle et al., 2003) are one way to gain insights into the fault system behavior, although current models are too simplistic to capture the full spatiotemporal behaviors of mid-continental earthquakes. Numerical simulations of fault interactions in a large system over multiple timescales (Li et al., 2009; Luo and Liu, 2010; 
Luo and Liu, 2012) have the potential to greatly improve understanding of spatiotemporal variability of large earthquakes in mid-continents, especially as the models improve with time by incorporating more realistic lithospheric structures, rheological properties, fault properties, and earthquake histories.

Part of this process should involve acquiring additional information, such as morphogenic, paleoseismic, and geodetic data beyond the sites of recent large earthquakes. Even in the central US where the New Madrid seismic zone has dominated attention because of apparent repetitions of large earthquakes in the past few thousand years (Tuttle et al., 2002), increasing evidence (Figure 7) indicates that large earthquakes occurred in many other places both within and outside the Mississippi Embayment (Cox et al., 2010; Csontos et al., 2008; Tuttle et al., 2006).

We suggest four approaches to improve hazard assessment in mid-continents. First, we need to recognize, communicate, and work with the uncertainties involved. Recognizing the uncertainties and developing ways to present them would help users decide how much credence to place in hazard maps and make them more useful in formulating cost-effective hazard mitigation policies. For example, models should consider different probability density functions of earthquakes allowed by the limited data, including the possibility of a fractal rupture behavior, i.e., the Devil's Staircase functions (Figure 14). We then need to formulate hazard mitigation policies given the uncertainties. This involves robust risk management - accepting the uncertainty and developing policies to give acceptable results for a range of possible hazard and loss 
scenarios (Stein and Stein, 2014). This approach follows the famous adage that "all models are wrong, but some are useful."

Second, we should learn more about how well hazard maps work, which is crucial in deciding how much faith to put in them when making expensive policy decisions. A good analogy is weather forecasts, which are routinely evaluated to assess how well their predictions matched what occurred. This process involves agreed criteria for "good" and "bad" forecasts. Forecasts are tested against null hypotheses, including seeing if they do better than using the average of that date in previous years, or assuming that today's weather will be the same as yesterday's. Over the years, this process has significantly improved forecasts and estimates of their uncertainties. Similar testing of hazard maps requires criteria for comparing their predictions to shaking that occurred after they were published (Stein et al., 2015a). Such testing would show how well the maps worked, better assess their true uncertainties, and indicate whether changes in map-making methods over time give better maps.

Third, we need to integrate all observational data for mid-continental faults and interpret them in the context of dynamic systems. As the Wenchuan earthquake showed, although the fault slip rate and seismic activity were both low before the earthquake, large earthquakes on other faults in the region would have suggested that the Longmenshan fault system is capable of producing damaging earthquakes, and the lack of large earthquakes in the past millennium would have suggested possible long-term 
accumulation of strain energy that could lead to a major rupture (Liu et al., 2014a; Wang et al., 2010).

Fourth, and most challenging, is to improve our understanding of the dynamics of intraplate fault interaction. As discussed here, we are just beginning to develop such an understanding. Until we do so, we will not know how to use the observations fully, so large uncertainties remain. However, the new ideas that have been emerging in recent years are pointing to a way forward.

\section{CONCLUSIONS}

Large earthquakes in mid-continents show complex spatiotemporal patterns that do not fit existing earthquake models. On individual mid-continental faults or fault zones, the occurrence of large earthquakes is temporally clustered, separated by long time (thousands of years or longer) of dormancy, much like typical Devil's Staircase functions. Spatially, these large mid-continental earthquakes tend to roam between widespread fault systems. Such spatiotemporal behavior indicates that fault systems in mid-continents, and the earthquakes on them, interact with each other in a complex dynamic system.

In such a system, widespread mid-continental faults collectively accommodate slow tectonic loading from the far field (plate boundary forces). The low loading rates mean that stress accumulation on any given fault is slow and susceptible to stress perturbations by failure of other faults in the system, or changing nontectonic stresses such as erosion. 
A major rupture (or ruptures) of a mid-continental fault would both cause stress transfer to neighboring faults and perturb loading conditions on distant faults, causing longdistance roaming of large earthquakes. Hence, the commonly used models, such as recurrence intervals and characteristic earthquakes, are especially inadequate or inapplicable in mid-continents.

Understanding the spatiotemporal variability of large mid-continental earthquakes requires not only more data but also a new approach - treating mid-continental faults not as individual faults but as a complex dynamic system. Adopting this approach involves giving up the hope of precisely predicting the evolution of fault ruptures, but instead trying to understand their qualitative system behavior. This approach calls for data collection and strain rate monitoring to go beyond areas where recent large earthquakes occurred, advanced numerical studies of fault interaction over multiple timescales in midcontinents, and hazard assessments that are not overly biased by the short and incomplete earthquake records in most regions.

Acknowledgement. We have benefitted from discussions with E. Brooks, E. Calais, T, Camelbeeck, J. Cheng, Q. Li, G. Luo, M. Merino, A. Newman, R. Geller, B. Spencer, K. Vanneste, B. Vleminckx, H. Wang, and J. Ye, who coauthored many papers we reviewed here. We thank Tim Horscroft for inviting us to write this review, editor Panza for handling the paper, and A. Peresan and an anonymous reviewer for their constructive comments. M. L. acknowledges support from NSF (grants EAR-1519980 and OISE0730154) and NSF of China (grant 41374104). 


\section{REFERENCES}

Al Shukri, H.J. and Mitchell, B.J., 1988. Reduced seismic velocities in the source zone of New Madrid earthquakes. Bulletin of the Seismological Society of America, 78(4): 1491-1509.

Artyushkov, E.V., 1973. Stresses in the lithosphere caused by crustal thickness inhomogeneities. J. Geophys. Res., 78: 7675-7690.

Bao, X., Xu, M., Wang, L., Mi, N., Yu, D. and Li, H., 2011. Lithospheric structure of the Ordos Block and its boundary areas inferred from Rayleigh wave dispersion. Tectonophysics, 499(1): 132-141.

Becker, T.W., Hardebeck, J.L. and Anderson, G., 2005. Constraints on fault slip rates of the southern California plate boundary from GPS velocity and stress inversions. Geophysical Journal International, 160: 634-650.

Bennett, R., Friedrich, A. and Furlong, K., 2004. Codependent histories of the San Andreas and San Jacinto fault zones from inversion of fault displacement rates.

Bilham, R., 2014. Aggravated Earthquake Risk in South Asia: Engineering versus Human Nature. In: M. Wyss (Editor), Earthquake Hazard, Risk, and Disasters. Elsevier, Amsterdam, pp. 103-141.

Brothers, D.S., Luttrell, K.M. and Chaytor, J.D., 2013. Sea-level-induced seismicity and submarine landslide occurrence. Geology, 41(9): 979-982.

Burdick, S., van der Hilst, R.D., Vernon, F.L., Martynov, V., Cox, T., Eakins, J., Karasu, G.H., Tylell, J., Astiz, L. and Pavlis, G.L., 2012. Model Update March 2011: 
Upper Mantle Heterogeneity beneath North America from Traveltime

Tomography with Global and USArray Transportable Array Data. Seismological Research Letters, 83(1): 23-28.

Burdick, S., Van der Hilst, R.D., Vernon, F.L., Martynov, V., Cox, T., Eakins, J., Karasu, G.H., Tylell, J., Astiz, L. and Pavlis, G.L., 2014. Model Update January 2013: Upper Mantle Heterogeneity beneath North America from Travel - Time Tomography with Global and USArray Transportable Array Data. Seismological Research Letters, 85(1): 77-81.

Calais, E., Camelbeeck, T., Stein, S., Liu, M. and Craig, T.J., 2016. A new paradigm for large earthquakes in stable continental plate interiors. Geophys. Res. Lett: in press.

Calais, E., Freed, A.M., Van Arsdale, R. and Stein, S., 2010. Triggering of New Madrid seismicity by late-Pleistocene erosion. Nature, 466(7306): 608-611.

Calais, E., Han, J., DeMets, C. and Nocquet, J., 2006. Deformation of the North American plate interior from a decade of continuous GPS measurements. Journal of Geophysical Research: Solid Earth (1978-2012), 111(B6).

Calais, E. and Stein, S., 2009. Time-variable deformation in the New Madrid Seismic Zone. Science, 323(5920): 1442.

Camelbeeck, T., Alexandre, P., Sabbe, A., Knuts, E., Garcia Moreno, D. and Lecocq, T., 2014. The impact of the earthquake activity in Western Europe from the historical and architectural heritage In: Talwani P (ed) Intraplate Earthquakes-Solid Earth Geophysics. Cambridge University Press.

Camelbeeck, T., Vanneste, K., Alexandre, P., Verbeeck, K., Petermans, T., Rosset, P., Everaerts, M., Warnant, R. and Van Camp, M., 2007. Relevance of active faulting 
and seismicity studies to assess long term earthquake activity in Northwest Europe. In: S. Stein and S. Mazzotti (Editors). Continental Intraplate Earthquakes: science, hazard, and policy issues. Geological Society of America, pp. 193-224.

Chen, Y., Tsoi, K.L., Chen, F.B., Gao, Z.H., Zou, Q.J. and Chen, Z.L., 1988. The great Tangshan earthquake of 1976: an anatomy of disaster. Pergamon Press, Oxford, $153 \mathrm{pp}$.

Chu, R., Leng, W., Helmberger, D.V. and Gurnis, M., 2013. Hidden hotspot track beneath the eastern United States. Nature Geoscience, 6(11): 963-966.

Clark, D., 2003. Earthquakes move on but not without a trace. AusGEO News, 70: 30-35.

Clark, D. and McCue, K., 2003. Australian paleoseismology: Towards a better basis for seismic hazard estimation. Annals of Geophysics, 46(5): 1087-1106.

Clark, D., McPherson, A. and Allen, T., 2014. Intraplate earthquakes in Australia. Intraplate Earthquakes. Cambridge University Press, New York: 8-49.

Clark, D., McPherson, A. and Collins, C., 2011. Australia's seismogenic neotectonic record. Geoscience Australia Record, 11.

Clark, D., McPherson, A. and Van Dissen, R., 2012. Long-term behaviour of Australian stable continental region (SCR) faults. Tectonophysics, 566: 1-30.

Costain, J.K., Bellinger, G.A. and Speer, J.A., 1987. Hydroseismicity-A hypothesis for the role of water in the generation of intraplate seismicity. Geology, 15(7): 618621.

Cox, R.T., Gordon, J., Forman, S., Brezina, T., Negrau, M., Hill, A., Gardner, C. and Machin, S., 2010. Paleoseismic sand blows in north Louisiana and south Arkansas. Seismological Research Letters, 81(6): 1032-1047. 
Cox, R.T., Hill, A.A., Larsen, D., Holzer, T., Forman, S.L., Noce, T., Gardner, C. and Morat, J., 2007. Seismotectonic implications of sand blows in the southern Mississippi Embayment. Engineering Geology, 89(3-4): 278-299.

Cox, R.T., Van Arsdale, R., Clark, D., Hill, A. and Lumsden, D., 2013. A Revised Paleo - Earthquake Chronology on the Southeast Reelfoot Rift Margin near Memphis, Tennessee. Seismological Research Letters, 84(2): 402-408.

Cox, R.T. and Van Arsdale, R.B., 1997. Hotspot origin of the Mississippi Embayment and its possible impact on contemporary seismicity. Engineering Geology, 46(34): 201-216.

Craig, T., Jackson, J., Priestley, K. and McKenzie, D., 2011. Earthquake distribution patterns in Africa: their relationship to variations in lithospheric and geological structure, and their rheological implications. Geophysical Journal International, 185(1): 403-434.

Crone, A., Machette, M. and Bowman, J., 1997. Episodic nature of earthquake activity in stable continental regions revealed by palaeoseismicity studies of Australian and North American Quaternary faults. Australian Journal of Earth Sciences, 44(2): 203-214.

Crone, A.J., De Martini, P.M., Machette, M.M., Okumura, K. and Prescott, J.R., 2003. Paleoseismicity of two historically quiescent faults in Australia: Implications for fault behavior in stable continental regions. Bulletin of the Seismological Society of America, 93(5): 1913-1934.

Crone, A.J. and Luza, K.V., 1990. Style and timing of Holocene surface faulting on the Meers fault, southwestern Oklahoma. GSA Bull., 102: 1-17. 
Csontos, R., Van Arsdale, R., Cox, R. and Waldron, B., 2008. Reelfoot rift and its impact on Quaternary deformation in the central Mississippi River valley. Geosphere, 4(1): $145-158$.

DeMets, C., Gordon, R.G., Argus, D.F. and Stein, S., 1990. Current plate motions. Int. J. Geophys., 101: 425-478.

Devaney, R.L., Devaney, L. and Devaney, L., 1989. An introduction to chaotic dynamical systems, 13046. Addison-Wesley Reading.

Dixon, T.H., Mao, A. and Stein, S., 1996. How rigid is the stable interior of the North American plate? Geophys. Res. Lett, 23: 3035-3038.

Doglioni, C. and Panza, G., 2015. Chapter One - Polarized Plate Tectonics. In: D. Renata (Editor), Advances in Geophysics. Elsevier, pp. 1-167.

Dolan, J., Bowman, D. and Sammis, C., 2007. Long-range and long-term fault interactions in Southern California. Geology.

Ebel, J.E., 2011. A new analysis of the magnitude of the February 1663 earthquake at Charlevoix, Quebec. Bulletin of the Seismological Society of America, 101(3): 1024-1038.

Ebel, J.E., Bonjer, K.-P. and Oncescu, M.C., 2000. Paleoseismicity: Seismicity evidence for past large earthquakes. Seismological Research Letters, 71(2): 283-294.

England, P. and Jackson, J., 2011. Uncharted seismic risk. Nature Geoscience, 4(6): 348349.

Fialko, Y., 2006. Interseismic strain accumulation and the earthquake potential on the southern San Andreas fault system. Nature, 441: 968-971. 
Flesch, L.M., Holt, W.E., Haines, A.J. and Shen, T.B., 2000. Dynamics of the PacificNorth American plate boundary in the Western United States. Science, 287(5454): 834-836.

Forte, A.M., Mitrovica, J.X., Moucha, R., Simmons, N.A. and Grand, S.P., 2007. Descent of the ancient Farallon slab drives localized mantle flow below the New Madrid seismic zone. Geophysical Research Letters, 34(4).

Forte, A.M., Moucha, R., Simmons, N.A., Grand, S.P. and Mitrovica, J.X., 2010. Deepmantle contributions to the surface dynamics of the North American continent. Tectonophysics, 481(1-4): 3-15.

Frankel, A., Smalley, R. and Paul, J., 2012. Significant motions between GPS sites in the New Madrid region: Implications for seismic hazard. Bulletin of the Seismological Society of America, 102(2): 479-489.

Frankel, A.D., Mueller, C., Barnhard, T., Perkins, D., Leyendecker, E., Dickman, N., Hanson, S. and Hopper, M., 1996. National seismic-hazard maps: documentation June 1996. US Geological Survey Reston, VA.

Freed, A., Ali, S. and Bürgmann, R., 2007. Evolution of stress in Southern California for the past 200 years from coseismic, postseismic and interseismic stress changes. Geophysical Journal International.

Geller, R.J., 2011. Shake-up time for Japanese seismology. Nature, 472(7344): 407-409.

Geller, R.J., Jackson, D.D., Kagan, Y.Y. and Mulargia, F., 1997. Earthquakes Cannot Be Predicted. Science, 275(5306): 1616-0.

Ghosh, A., Becker, T. and Humphreys, E., 2013. Dynamics of the North American continent. Geophysical Journal International: doi: 10.1093/gji/ggt151. 
Ghosh, A. and Holt, W.E., 2012. Plate Motions and Stresses from Global Dynamic Models. Science, 335(6070): 838-843.

Goes, S. and van der Lee, S., 2002. Thermal structure of the North American uppermost mantle inferred from seismic tomography. Journal of Geophysical Research, 107(B3): 2050, doi:10.1029/2000JB000049.

Gordon, D.W., 1983. Revised hypocenters and correlation of seismicity and tectonics in the central United States. Ph.D. Thesis, St. Louis University, St. Louis, Missouri, 199 pp.

Grana, J.P. and Richardson, R.M., 1996. Tectonic stress within the New Madrid seismic zone. Journal of Geophysical Research, 101(3): 5445-5458.

Grollimund, B. and Zoback, M.D., 2001. Did deglaciation trigger intraplate seismicity in the New Madrid seismic zone? Geology (Boulder), 29(2): 175-178.

Guo, L., Magnani, M.B., McIntosh, K. and Waldron, B., 2014. Quaternary deformation and fault structure in the Northern Mississippi Embayment as imaged by nearsurface seismic reflection data. Tectonics, 33(5): 2013 TC003464.

Hao, Y., Magnani, M.B., McIntosh, K., Waldron, B. and Guo, L., 2013. Quaternary deformation along the Meeman - Shelby Fault near Memphis, Tennessee, imaged by high - resolution marine and land seismic reflection profiles. Tectonics.

Hebden, J.S. and Stein, S., 2009. Time-dependent seismic Hazard maps for the New Madrid Seismic Zone and Charleston, South Carolina, areas. Seismological Research Letters, 80(1): 12-20.

Holbrook, J., Autin, W.J., Rittenour, T.M., Marshak, S. and Goble, R.J., 2006. Stratigraphic evidence for millennial-scale temporal clustering of earthquakes on 
a continental-interior fault: Holocene Mississippi River floodplain deposits, New Madrid seismic zone, USA. Tectonophysics, 420(3-4): 431-454.

Hough, S. and Page, M., 2011. Toward a consistent model for strain accrual and release for the New Madrid Seismic Zone, central United States. J. Geophys. Res., 116: doi:10.1029/2010JB007783.

Hough, S.E., Armbruster, J.G., Seeber, L. and Hough, J.F., 2000. On the modified Mercalli intensities and magnitudes of the 1811-1812 New Madrid earthquakes. Journal of Geophysical Research, B, Solid Earth and Planets, 105(10): 23,83923,864 .

Huang, J. and Turcotte, D.L., 1990. Are earthquakes an example of deterministic chaos? Geophysical Research Letters, 17(3): 223-226.

Huang, W.Q., Li, W.X. and Cao, X.F., 1994. Research on the completeness of earthquake data in the Chinese mainland (I). Acta Seismologica Sinica, 16(3): 273-280.

Hurd, O. and Zoback, M.D., 2012. Intraplate earthquakes, regional stress and fault mechanics in the Central and Eastern U.S. and Southeastern Canada. Tectonophysics(0): doi:10.1016/j.tecto.2012.04.002.

Isacks, B., Oliver, J. and Sykes, L.R., 1968. Seismology and the new global tectonics. Journal of Geophysical Research, 73(18): 5855-5899.

Jackson, D.D. and Kagan, Y.Y., 2006. The 2004 Parkfield Earthquake, the 1985 Prediction, and Characteristic Earthquakes: Lessons for the Future. Bulletin of the Seismological Society of America, 96(4B): S397-409.

Johnston, A.C. and Kanter, L.R., 1990. Earthquakes in stable continental crust. Sci. Am., 262(3): 68-75. 
Johnston, A.C. and Schweig, E.S., 1996. The enigma of the New Madrid earthquakes of 1811-1812. Annual Review of Earth and Planetary Sciences.

Kagan, Y., 1993. Statistics of characteristic earthquakes. Bulletin of the Seismological Society of America, 83(1): 7-24.

Kanamori, H. and Brodsky, E.E., 2004. The physics of earthquakes. Reports on Progress in Physics, 67(8): 1429.

Keilis-Borok, V., 1990. The lithosphere of the Earth as a nonlinear system with implications for earthquake prediction. Reviews of Geophysics, 28(1): 19-34.

Kenner, S.J. and Segall, P., 2000. A mechanical model for intraplate earthquakes; application to the New Madrid seismic zone. Science, 289(5488): 2329-2332.

King, G.C.P., Stein, R.S. and Lin, J., 1994. Static stress changes and the triggering of earthquakes. Bulletin of the Seismological Society of America, 84(3): 935-953.

Kusters, D., 2014. Etude des sources locales de contraintes et des variations spatiotemporelles de l'activite' sismique a' l'inte' rieur de la plaque europe'enne, Univesite’ Libre de Bruxelles.

Landgraph, A., Kubler, S., Hintersberger, E. and Stein, S., 2015. Seismicity, Fault Rupture and Earthquake Hazards in Slowly Deforming Regions, 432. Geological Society of London, Special Publications series.

Leydecker, G., 2011. Earthquake Catalogue for Germany and Adjacent Areas. http://www.bgr.bund.de/EN/Themen/Seismologie/Erdbebenauswertung_en/Katal oge_en/historisch/germany_en.html. 
Li, Q., Liu, M. and Sandvol Eric, A., 2005. Stress Evolution Following the 1811-1812 Large Earthquakes in the New Madrid Seismic Zone. Geophys. Res. Lett, 32(L11310): doi:10.1029/2004GL022133.

Li, Q., Liu, M. and Stein, S., 2009. Spatial-temporal complexity of continental intraplate seismicity: Insights from geodynamic modeling and implications for seismic hazard estimation. Bulletin of the Seismological Society of America, 99(1): doi: $10.1785 / 0120080005$.

Li, Q., Liu, M. and Yang, Y., 2002. The 01/26/2001 Bhuj, India, earthquake: intraplate or interplate? In: S. Stein and J. Freymueller (Editors), Plate Boundary Zone. American Geophysical Union, Washington, D.C., pp. 255-264.

Li, Q., Liu, M., Zhang, Q. and Sandvol, E., 2007. Stress evolution and seismicity in the central-eastern United States: Insights from geodynamic modeling. In: S. Stein and S. Mazzotti (Editors), Continental Intraplate Earthquakes: Science, Hazard, and Policy Issues. Geological Society of America Special Paper, pp. 149-166, doi: 10.1130/2007.2425.

Liu, M., Cui, X. and Liu, F., 2004. Cenozoic rifting and volcanism in eastern China: a mantle dynamic link to the Indo-Asian collision? Tectonophysics, 393: 29-42.

Liu, M., Luo, G. and Wang, H., 2014a. The 2013 Lushan earthquake in China tests hazard assessments. Seismological Research Letters, 85(1): 40-43.

Liu, M., Luo, G., Wang, H. and Stein, S., 2014b. Long aftershock sequences in North China and Central US: implications for hazard assessment in mid-continents. Earthquake Science: DOI 10.1007/s11589-014-0066-z. 
Liu, M. and Stein, S., 2011. Aftershocks. In: H. Gupta (Editor), Encyclopedia of Solid Earth Geophysics. Springer Dordrecht, The Netherlands, pp. 192-194.

Liu, M., Stein, S. and Wang, H., 2011. 2000 years of migrating earthquakes in North China: How earthquakes in midcontinents differ from those at plate boundaries. Lithosphere: $128-132$

Liu, M. and Wang, H., 2012. Roaming earthquakes in China highlight midcontinental hazards. EOS, 93(45): 453-454.

Liu, M., Wang, H. and Li, Q., 2010. Inception of the eastern California shear zone and evolution of the Pacific-North American plate boundary: From kinematics to geodynamics. J. Geophy. Res., 115(B7): B07401.

Liu, M., Wang, H., Ye, J. and Cheng, J., 2014c. Intraplate earthquakes in North China. In: P. Talwani (Editor), Intraplate Earthquakes. Cambridge University Press, New York, pp. 97-125.

Liu, M. and Yang, Y., 2005. Contrasting seismicity between the North China and South China blocks: kinematics and geodynamic. Geophys. Res. Lett, 32(L12310): doi:10.1029/2005GL023048.

Liu, M., Yang, Y., Shen, Z., Wang, S., Wang, M. and Wan, Y., 2007. Active tectonics and intracontinental earthquakes in China:The kinematics and geodynamics. In: S. Stein and S. Mazzotti (Editors), Continental Intraplate Earthquakes: Science, Hazard, and Policy Issues. Geological Society of America Special Papers, Boulder, CO, pp. 209-318, doi: 10.1130/2007.2425.

Lorenz, E.N., 1963. Deterministic nonperiodic flow. Journal of the atmospheric sciences, 20(2): 130-141. 
Ludwig, L.G., Akçiz, S.O., Noriega, G.R., Zielke, O. and Arrowsmith, J.R., 2010. Climate-Modulated Channel Incision and Rupture History of the San Andreas Fault in the Carrizo Plain. Science, 327(5969): 1117-1119.

Luo, G. and Liu, M., 2010. Stress evolution and fault interactions before and after the 2008 Great Wenchuan Earthquake. Tectonophysics:

doi:10.1016/j.tecto.2009.12.019.

Luo, G. and Liu, M., 2012. Multi-timescale mechanical coupling between the San Jacinto Fault and the San Andreas Fault, southern California. Lithosphere: doi: 10.1130/L180.1.

Ma, X., 1989. Lithospheric dynamics altas of China. China Cartographic Publishing House, Beijing.

Madole, R.F. and Rubin, M., 1985. Holocene movement on the Meers Fault, Southwest Oklahoma, The Seismological Society of America, 1985, annual meeting. Seismological Society of America Eastern Section, [El Cerrito, CA], United States, pp. 1-2.

Manaker, D.M., Calais, E., Freed, A., Ali, S., Przybylski, P., Mattioli, G., Jansma, P., Prépetit, C. and De Chabalier, J., 2008. Interseismic plate coupling and strain partitioning in the northeastern Caribbean. Geophysical Journal International, 174(3): 889-903.

Marone, F., Gung, Y. and Romanowicz, B., 2007. Three-dimensional radial anisotropic structure of the North American upper mantle from inversion of surface waveform data. Geophysical Journal International, 171(1): 206-222. 
Mazzotti, S., 2007. Geodynamic models for earthquake studies in intraplate North America. Geological Society of America Special Papers, 425: 17-33.

McGarr, A. and Gay, N.C., 1978. State of stress in the Earth's crust. Ann. Rev. Earth Planet. Sci., 6: 405-435.

McKenna, J., Stein, S. and Stein, C., 2007. Is the New Madrid seismic zone hotter and weaker than its surroundings? In: S.S.a.S. Mazzotti (Editor), Continental Intraplate Earthquakes: Science, Hazard, and Policy Issues. Geol. Soc. Am, Boulder,Colorado, pp. 167-175.

Meade, B.J. and Hager, B.H., 2005. Spatial localization of moment deficits in southern California. J. Geophys. Res.(110): doi:10.1029/2004JB003331.

Meghraoui, M., Delouis, B., Ferry, M., Giardini, D., Huggenberger, P., Spottke, I. and Granet, M., 2001. Active normal faulting in the Upper Rhine Graben and paleoseismic identification of the 1356 Basel earthquake. Science, 293(5537): 2070-2073.

Merino, M., 2014. Tectonics and seismicity of rifts past and present, Northwestern University.

Ming, Z., Hu, G., Jiang, X., Liu, S. and Yang, Y., 1995. Catalog of Chinese historic strong earthquakes from 23 AD to 1911. Seismol. Press, Beijing: 514.

Mooney, W.D., Ritsema, J. and Hwang, Y.K., 2012. Crustal seismicity and the earthquake catalog maximum moment magnitude (Mcmax) in stable continental regions (SCRs): Correlation with the seismic velocity of the lithosphere. Earth and Planetary Science letters, 357-358: 78-83. 
Newman, A., Schneider, J., Stein, S. and Andres, M., 2001. Uncertainties in seismic hazard maps for the New Madrid Seismic Zone and implications for seismic hazard communication. Seismological Research Letters, 72(6): 647-663.

Newman, A., Stein, S., Weber, J., Engeln, J., Mao, A. and Dixon, T., 1999. Slow deformation and lower seismic hazard at the New Madrid Seismic Zone. Science, 284(5414): 619-621.

Nishenko, S.P., 1991. Circum-Pacific seismic potential: 1989-1999. Pure and Applied Geophysics, 135(2): 169-259.

Nuttli, O.W., Bollinger, G.A. and Griffiths, D.W., 1979. On the relation between modified Mercalli intensity and body-wave magnitude. Bulletin of the Seismological Society of America, 69(3): 893-909.

Obermeier, S.F., 1999. Seismic liquefaction features examples from paleoseismic investigations in the continental United States. US Geological Survey; USGS Information Services (Open-File Report Sales)].

Obermeier, S.F., Gohn, G.S., Weems, R.E., Gelinas, R.L. and Rubin, M., 1985. Geologic evidence for recurrent moderate to large earthquakes near Charleston, South Carolina. Science, 227(4685): 408-411.

Omori, F., 1894. On the aftershocks of earthquakes. Journal of the College of Science, Imperial University of Tokyo, 7: 111-200.

Parsons, T., 2002. Global Omori law decay of triggered earthquakes: Large aftershocks outside the classical aftershock zone. Journal of Geophysical Research B: Solid Earth, 107(9): 9-1. 
Parsons, T., Ji, C. and Kirby, E., 2008. Stress changes from the 2008 Wenchuan earthquake and increased hazard in the Sichuan basin. Nature, 454(7203): 509510.

Peresan, A., Kossobokov, V., Romashkova, L. and Panza, G.F., 2005. Intermediate-term middle-range earthquake predictions in Italy: a review. Earth-Science Reviews, 69(1-2): 97-132.

Pollitz, F.F., Kellogg, L. and Buergmann, R., 2001. Sinking mafic body in a reactivated lower crust; a mechanism for stress concentration at the New Madrid seismic zone. Bulletin of the Seismological Society of America, 91(6): 1882-1897.

Pollitz, F.F. and Mooney, W.D., 2013. Seismic structure of the Central US crust and shallow upper mantle: Uniqueness of the Reelfoot Rift. Earth and Planetary Science letters.

Pollitz, F.F. and Sacks, I.S., 2002. Stress triggering of the 1999 Hector Mine earthquake by transient deformation following the 1992 Landers earthquake. Bull. Seismol. Soc. Am., 92: 1487-1496.

Pratt, T.L., 2012. Kinematics of the New Madrid seismic zone, central United States, based on stepover models. Geology, 40(4): 371-374.

Ran, Y., Chen, L., Chen, J., Wang, H., Chen, G., Yin, J., Shi, X., Li, C. and Xu, X., 2010. Paleoseismic evidence and repeat time of large earthquakes at three sites along the Longmenshan fault zone. Tectonophysics, 491(1): 141-153.

Rastogi, B.K., Mandal, P. and Biswas, S.K., 2014. Seismogenesis of earthquakes occurring in the ancient rift basin of Kachchh, Western India. In: P. Talwani 
(Editor), Intraplate Earthquakes. Cambridge University Press, New York, pp. 126161.

Reid, H.F., 1910. The Mechanics of the Earthquake, The California Earthquake of April 18, 1906, Report of the State Investigation Commission. Vol. 2.

Rong, Y., Jackson, D.D. and Kagan, Y.Y., 2003. Seismic gaps and earthquakes. Journal of Geophysical Research: Solid Earth, 108(B10).

Rundle, J.B. and Jackson, D.D., 1977. Numerical simulation of earthquake sequences. Bulletin of the Seismological Society of America, 67(5): 1363-1377.

Rundle, J.B., Rundle, P.B., Donnellan, A., Li, P., Klein, W., Morein, G., Turcotte, D.L. and Grant, L., 2006. Stress transfer in earthquakes, hazard estimation and ensemble forecasting: Inferences from numerical simulations. Tectonophysics, 413(1-2): 109-125.

Rundle, J.B., Turcotte, D.L., Shcherbakov, R., Klein, W. and Sammis, C., 2003. Statistical physics approach to understanding the multiscale dynamics of earthquake fault systems. Reviews of Geophysics, 41(4).

Savage, J., 1991. Criticism of some forecasts of the national earthquake prediction evaluation council. Bulletin of the Seismological Society of America, 81(3): 862881.

Sbar, M.L. and Sykes, L.R., 1973. Contemporary Compressive Stress and Seismicity in Eastern North America; An Example of Intra-plate Tectonics. Geological Society of America Bulletin, 84(6): 1861-1881.

Scharer, K., 2010. Changing Views of the San Andreas Fault. Science, 327(5969): 10891090. 
Schulte, S.M. and Mooney, W.D., 2005. An updated global earthquake catalogue for stable continental regions: Reassessing the correlation with ancient rifts. Geophysical Journal International, 161(3): 707-721.

Schwartz, D.P. and Coppersmith, K.J., 1984. Fault behavior and characteristic earthquakes: Examples from the Wasatch and San Andreas fault zones. Journal of Geophysical Research: Solid Earth (1978-2012), 89(B7): 5681-5698.

Schweig, E.S. and Ellis, M.A., 1994. Reconciling short recurrence intervals with minor deformation in the New Madrid seismic zone. Science, 264(5163): 1308-1311.

Shen, Z.-K., Sun, J., Zhang, P., Wan, Y., Wang, M., Bürgmann, R., Zeng, Y., Gan, W., Liao, H. and Wang, Q., 2009. Slip maxima at fault junctions and rupturing of barriers during the 2008 Wenchuan earthquake. Nature Geoscience, 2(10): 718724.

Shen, Z.K., Zhao, C., Yin, A. and Jackson, D., 2000. Contemporary crustal deformation in east Asia constrained by Global Positioning System measurements. J. Geophy. Res., 105: 5721-5734.

Sieh, K.E. and Jahns, R.H., 1984. Holocene activity of the San Andreas Fault at Wallace Creek, California. Geological Society of America Bulletin, 95(8): 883-896.

Simkin, M. and Roychowdhury, V., 2014. Stochastic modeling of a serial killer. Journal of theoretical biology, 355: 111-116.

Stark, P.B. and Freedman, D.A., 2003. What is the chance of an earthquake? . In: F. Mulargia and R.J. Geller (Editors), Earthquake Science and Seismic Risk Reduction. Kluwer, Dordrecht, The Netherlands, pp. 201-213. 
Stein, R.S., 1999. The role of stress transfer in earthquake occurrence. Nature, 402: 605609.

Stein, S., 2010. Disaster Deferred: How New Science is Changing our View of Earthquake Hazards in the Midwest. Columbia University Press.

Stein, S., Cloetingh, S., Sleep, N.H. and Wortel, R., 1989. Passive margin earthquakes, stresses and rheology, Earthquakes at North-Atlantic Passive Margins: Neotectonics and Postglacial Rebound. Springer, pp. 231-259.

Stein, S. and Friedrich, A.M., 2014. How much can we clear the crystal ball? Astronomy \& Geophysics, 55(2): 2.11-2.17.

Stein, S., Geller, R. and Liu, M., 2011. Bad assumptions or bad luck: Why earthquake hazard maps need objective testing. Seis. Res. Lett., 82(5): 623-626.

Stein, S., Geller, R.J. and Liu, M., 2012. Why earthquake hazard maps often fail and what to do about it. Tectonophysics, 562-563(0): 1-25.

Stein, S. and Liu, M., 2009. Long aftershock sequences within continents and implications for earthquake hazard assessment. Nature, 462(7269): 87-89.

Stein, S., Liu, M., Calais, E. and Li, Q., 2009. Mid-Continent Earthquakes as a Complex System. Seismological Research Letters, 80(4): 551-553.

Stein, S., Liu, M., Camelbeeck, T., Merino, M., Landgraf, A., Hintersberger, E. and Kuebler, S., 2015a. Challenges in assessing seismic hazard in intraplate Europe. Geological Society, London, Special Publications, 432: SP432. 7.

Stein, S. and Okal, E.A., 2011. The size of the 2011 Tohoku earthquake need not have been a surprise. Eos, Transactions American Geophysical Union, 92(27): 227-228. 
Stein, S., Sleep, N.H., Geller, R.J., Wang, S.C. and Kroeger, G.C., 1979. Earthquakes along the passive margin of eastern Canada. Geophysical Research Letters, 6(7): $537-540$.

Stein, S., Spencer, B.D. and Brooks, E.M., 2015b. Metrics for Assessing Earthquake Hazard Map Performance. Bulletin of the Seismological Society of America, 105(4): 2160-2173.

Stein, S., Stein, C., Kley, J., R., K., M., M., Wolin, E., Wiens, D., Wysession, M., AlEquabi, M., Shen, W., Frederiksen, A., Darbyshire, F., Jurdy, D., Waite, G., Rose, W., E., V., T., R., Moucha, R. and Brown, E., 2016 New insights into North America's Midcontinent Rift. Eos, 97: doi:10.1029/2016EO056659.

Stein, S. and Stein, J., 2014. Playing Against Nature: Integrating Science and Economics to Mitigate Natural Hazards in an Uncertain World. John Wiley \& Sons.

Street, R. and Lacroix, A., 1979. An empirical study of New England seismicity: 17271977. Bulletin of the Seismological Society of America, 69(1): 159-175.

Strogatz, S.H., 2014. Nonlinear dynamics and chaos: with applications to physics, biology, chemistry, and engineering. Westview press.

Swafford, L. and Stein, S., 2007. Limitations of the short earthquake record for seismicity and seismic hazard studies. Geological Society of America Special Papers, 425: 49-58.

Sykes, L.R., 1978. Intraplate seismicity, reactivation of preexisting zones of weakness, alkaline magmatism, and other tectonism postdating continental fragmentation. Reviews of Geophysics and Space Physics, 16(4): 621-688. 
Talwani, P., 1988. The intersection model for intraplate earthquakes. Seismological Research Letters, 59(4): 305-310.

Talwani, P., 2014. Intraplate earthquakes. Cambridge University Press, New York, 338 pp.

Talwani, P. and Cox, J., 1985. Paleoseismic evidence for recurrence of earthquakes near Charleston, South Carolina. Science, 229(4711): 379-381.

Talwani, P. and Gangopadhyay, A., 2001. Tectonic framework of the Kachchh earthquake of 26 January 2001. Seismological Research Letters, 72: 336-345.

Tapponnier, P. and Molnar, P., 1977. Active faulting and tectonics in China. J. Geophys. Res., 82: 2905-2930.

Tapponnier, P., Peltzer, G., LeDain, A.Y., Armijo, R. and Cobbold, P., 1982. Propagating extrusion tectonics in Asia: New insights from simple experiments with plasticine. Geology, 10: 611-616.

Toro, G.R., Abrahamson, N.A. and Schneider, J.F., 1997. Model of strong ground motions from earthquakes in central and eastern North America: best estimates and uncertainties. Seismological Research Letters, 68(1): 41-57.

Turcotte, D.L., 1997. Fractals and chaos in geology and geophysics. Cambridge university press.

Turcotte, D.L. and Malamud, B.D., 2002. 14 earthquakes as a complex system. International Geophysics, 81: 209-IV.

Tuttle, M.P., 2009. Clustered Model for New Madrid Earthquakes. Central and Eastern United States Seismic Source Characterization Project: Workshop 2 Proceedings. 
Tuttle, M.P., Al-Shukri, H. and Mahdi, H., 2006. Very Large Earthquakes Centered Southwest of the New Madrid Seismic Zone 5,000-7,000 Years Ago. Seismological Research Letters, 77(6): 755-770.

Tuttle, M.P., Schweig, E.S., Sims, J.D., Lafferty, R.H., Wolf, L.W. and Haynes, M.L., 2002. The earthquake potential of the New Madrid seismic zone. Bulletin of the Seismological Society of America, 92(6): 2080-2089.

Van Arsdale, R., 2000. Displacement history and slip rate on the Reelfoot Fault of the New Madrid seismic zone. Engineering Geology, 55(4): 219-226.

Van Lanen, X. and Mooney, W.D., 2007. Integrated geologic and geophysical studies of North American continental intraplate seismicity. In: S.M. S. Stein (Editor). The Geological Society of America, Boulder, CO, pp. 101-112.

Van Schmus, W. and Hinze, W., 1985. The midcontinent rift system. Annual Review of Earth and Planetary Sciences, 13: 345.

Vanneste, K., Camelbeeck, T. and Verbeeck, K., 2013. A model of composite seismic sources for the lower Rhine Graben, northwest Europe. Bulletin of the Seismological Society of America, 103(2A): 984-1007.

Wald, D.J. and Heaton, T.H., 1994. Spatial and temporal distribution of slip for the 1992 Landers, California, earthquake. Bulletin of the Seismological Society of America, 84(3): 668-691.

Wang, H., Liu, M., Shen, X. and Liu, J., 2010. Balancing seismic moment in eastern Tibet: Implications for the Great 2008 Wenchuan Earthquake. Tectonophysics: doi:10.1016/j.tecto.2009.09.022. 
Wolin, E., Stein, S., Pazzaglia, F., Meltzer, A., Kafka, A. and Berti, C., 2012. Mineral, Virginia, earthquake illustrates seismicity of a passive-aggressive margin. Geophysical Research Letters, 39(2).

Xu, X. and Deng, Q., 1996a. Nonlinear characteristics of paleoseismicity in China. Journal of Geophysical Research: Solid Earth, 101(B3): 6209-6231.

Xu, X. and Deng, Q., 1996b. Nonlinear characteristics of paleoseismicity in China. Journal of Geophysical Research-Solid Earth, 101(B3): 6209-6231.

Xu, X. and Ma, X., 1992. Geodynamics of the Shanxi Rift system, China. Tectonophysics, 208: 325-340.

Xu, X., Wen, X., Yu, G., Chen, G., Klinger, Y., Hubbard, J. and Shaw, J., 2009. Coseismic reverse-and oblique-slip surface faulting generated by the $2008 \mathrm{Mw}$ 7.9 Wenchuan earthquake, China. Geology, 37(6): 515-518.

Yang, Y. and Liu, M., 2010. What drives short- and long-term crustal deformation in the southwestern United States? Geophys. Res. Lett., 37(L04306): doi:10.1029/2009GL041598.

Yin, A., Yu, X., Shen, Z.-K. and Liu-Zeng, J., 2015. A possible seismic gap and high earthquake hazard in the North China Basin. Geology, 43(1): 19-22.

Yuan, H. and Romanowicz, B., 2010. Lithospheric layering in the North American craton. Nature, 466(7310): 1063-1068.

Zeigler, B.P., Praehofer, H. and Kim, T.G., 2000. Theory of modeling and simulation: integrating discrete event and continuous complex dynamic systems. Academic press. 
Zhang, Q., Sandvol, E. and Liu, M., 2009. Lithospheric velocity structure of the New Madrid Seismic Zone: A joint teleseismic and local P tomographic study. Geophysical Research Letters, 36(11): L11305.

Zhang, Y., Ma, Y., Yang, N., Shi, W. and Dong, S., 2003. Cenozoic extensional stress evolution in North China. Geodynamics, 36: 591-613.

Zielke, O., Arrowsmith, J.R., Ludwig, L.G. and Akçiz, S.O., 2010. Slip in the 1857 and Earlier Large Earthquakes Along the Carrizo Plain, San Andreas Fault. Science, 327(5969): 1119-1122.

Zoback, M.D., 1983. A new data source for in situ stress field orientations. Nature (London), 306(5938): 18.

Zoback, M.L. and Zoback, M.D., 1980. State of stress in the conterminous United States. Journal of Geophysical Research, 85(11): 6113-6156. 